225. LC

Draft

Published in Journal of Law and Religion 30 (2015): 353-385

\title{
Christianity and Human Rights: Past Contributions and Future Challenges
}

John Witte, Jr. 1 and Justin J. Latterell2

\begin{abstract}
This Article analyzes the historical sources and forms of human rights in Western legal and Christian traditions, and identifies key questions about the intersections of Christianity and human rights in modern contexts. The authors identify nine distinctions between different conceptions of rights correlating with four types of jural relationships, and argue that leading historical accounts of human rights attribute "subjective" rights too narrowly to Enlightenment and post-Enlightenment legal thought. Earlier forms of classical Roman law and medieval canon law, and legal norms developed by Protestant reformers of the sixteenth and seventeenth centuries shaped Western human rights regimes in historically important ways, anticipating most of the rights formulation of modern liberals. In response to contemporary scholars who criticize human rights paradigms as inadequate or incompatible with Christian faith and practice, the authors argue that rights should remain a part of Christian moral, legal, and political discourse, and that Christians should remain a part of pluralistic public debates about the appropriate scope and substance of human rights protections.
\end{abstract}

Keywords: Christianity; human rights; freedom; subjective rights; objective right; Bible; Catholicism; Second Vatican Council; rights skepticism; rights critique; Enlightenment; political liberalism; Leo Strauss; prisoners; African-Americans; civil rights movement; Martin Luther King, Jr.; Bible; creation; image of God; Desmond Tutu; spiritual liberty; covenant; separation of church and state; Roman law; ius; libertas; facultas; Edict of Milan; natural law; freedom of the church; Papal Revolution; Thomas Aquinas; Jean Porter; medieval canon law; Magna Carta; Protestantism; three estates theory; Decalogue; rights and duties; cuius regio, eius religio; Peace of Augsburg; Peace of Westphalia;

\footnotetext{
1 Robert W. Woodruff Professor of Law; Alonzo L. McDonald Distinguished Professor; and Director, Center for the Study of Law and Religion, Emory University School of Law.

2 Alonzo L. McDonald Senior Fellow in Law and Religion, Center for the Study of Law and Religion, Emory University School of Law.
} 
Lutheranism; Anabaptism; Anglicanism; John Calvin; Calvinism; Virginia Declaration of Rights; First Amendment; U.S. Bill of Rights; French Declaration of the Rights of Man and Citizen; uses of law;

\section{Introduction}

Fifty years ago, the world welcomed some of the most remarkable human rights documents it had ever seen. The United States Congress passed the Civil Rights Act of 1964 and the Voting Right Act of 1965.3 This was America's strongest statutory rebuke to its long and tragic history of racism, chauvinism, nativism, and religious and cultural bigotry. Born of the civil rights movement and inspired especially by African-American churches, 4 these two acts declared anathema on all manner of discrimination in the voting booth, in public accommodations, in schools, and in the workplace. They called American courts and citizens to give full and faithful protection to the rights of everyone regardless of race, color, religion, sex, or national origin. And they called America back not only to the high promise of the Reconstruction Amendments ratified in the aftermath of the Civil War, 5 but also to the founding ideals set out in its ur text, the Declaration of Independence: "that all men [now persons] are created equal, that they are endowed by their Creator with certain unalienable Rights, that among these are Life, Liberty and the pursuit of Happiness." 6

Fifty years ago, the Second Vatican Council, speaking to and for a billion plus Catholics world-wide, opened up a new chapter in its mission and ministry with a series of sweeping new papal and conciliar declarations - Pacem in Terris, Dignitatis Humanae, Gaudium et Spes, and Lumen Gentium. 7 Rejecting its anti-democratic and anti-rights posture of a century before, the Catholic Church now taught that each and every human being is created by God with "dignity, intelligence and free will ... and has rights flowing directly and simultaneously from their very nature."8 Such rights include the right to life and adequate standards of living, to moral and cultural values, to religious activities, to assembly and association, to marriage and family life, and to various social, political, and economic benefits and opportunities. The Church emphasized the religious rights of conscience, worship, assembly, and education, calling them the "first rights" of any civic order.9 It also stressed the need to balance individual and associational rights, particularly those involving the church, family, and

\footnotetext{
378 Stat. 241; 79 Stat. 437.

4 See Robert M. Franklin, "Rehabilitating Democracy: Restoring Civil Rights and Leading the Next Human Rights Revolution," (herein).

5 See U.S. Const. amend. XIII; U.S. Const. amend XIV; U.S. Const. amend XV.

6 U.S. Declaration of Independence (1776), paragraph 2.

7 See Russell Hittinger, "An Issue of First Importance: Reflections on the $50^{\text {th }}$ Anniversary of Dignitatis Humanae," (herein).

8 Pacem in Terris, para. 9 (1963), reprinted in Joseph Gremillion, ed., The Gospel of Peace and Justice: Catholic Social Teaching Since Pope John (Maryknoll, N.Y.: Orbis, 1976), 203.

9 Ibid., 203-18.
} 
school. It urged the abolition of discrimination on grounds of sex, race, color, social distinction, language, and religion. And the Church called on clergy and laity alike to be ambassadors and advocates for the rights of all persons, especially the "least" of God's children, as the Bible called them - the poor, needy, sick, and handicapped; widows, orphans, and sojourners; the incarcerated and incapacitated; and children, born and unborn. 10

And fifty years ago, the United Nations, embracing almost all 186 nation-states around the world at the time, passed the International Covenant on Civil and Political Rights and the International Covenant on Economic, Social, and Cultural Rights.11 Only two decades before passage of these twin covenants, the world had stared in horror into Hitler's death camps and Stalin's gulags where all sense of humanity and dignity had been brutally sacrificed. It had witnessed the slaughter of 60 million people around the world in six years of unprecedented brutality. In response, the world had seized anew on the ancient concept of human dignity, claiming this as the "ur-principle" of a new world order. 12 The Universal Declaration of Human Rights of 1948 opened its preamble with the classic words: "recognition of the inherent dignity and of the equal and inalienable rights of all members of the human family is the foundation of freedom, justice, and peace in the world." 13 The 1966 international Covenants sought to translate the general principles of the Universal Declaration into more specific precepts. The International Covenant on Economic, Social, and Cultural Rights (1966) posed as essential to human dignity the rights to self-determination, subsistence, work, welfare, security, education, and cultural participation. ${ }^{14}$ The International Covenant on Civil and Political Rights (1966) set out a long catalogue of rights to life and to security of person and property, freedom from slavery and cruelty, basic civil and criminal procedural protections, rights to travel and pilgrimage, freedoms of religion, expression, and assembly, rights to marriage and family life, and freedom from discrimination on grounds of race, color, sex, language, and national origin. 15 These documents were declarations of both hope and repentance - expressions of sober optimism about the

10 lbid.

11 See lan Brownlie and Guy S. Goodwin-Gill, eds., Basic Documents on Human Rights, 6th ed., (Oxford; New York: Oxford University Press, 2010), 370-379; 388-404. These documents are also available online. See: "International Covenant on Civil and Political Rights,"

http://www.ohchr.org/en/professionalinterest/pages/ccpr.aspx; and "International Covenant on Economic, Social, and Cultural Rights," http://www.ohchr.org/EN/Professionallnterest/Pages/CESCR.aspx, accessed March 17, 2015.

12 The term "ur-principle" is from Louis Henkin et al., Human Rights (New York: Foundation, 1999), p. 80.

13 Universal Declaration of Human Rights (1948), in See lan Brownlie and Guy S. Goodwin-Gill, eds., Basic Documents on Human Rights, 6th ed., (Oxford; New York: Oxford University Press, 2010), 39-44. See online resource, "Universal Declaration of Human Rights," http://www.ohchr.org/EN/UDHR/Pages/Introduction.aspx, accessed March 17, 2015.

14 See "International Covenant on Economic, Social, and Cultural Rights," in lan Brownlie and Guy S. Goodwin-Gill, eds., Basic Documents on Human Rights, 6th ed., (Oxford; New York: Oxford University Press, 2010), 370-379.

15 "International Covenant on Civil and Political Rights," lan Brownlie and Guy S. Goodwin-Gill, eds., Basic Documents on Human Rights, 6th ed., (Oxford; New York: Oxford University Press, 2010), 388404. 
human condition, and of the pressing need to prevent further catastrophes. 16 They have inspired a whole series of subsequent international and domestic human rights instruments designed to broaden the human rights regime, and to extend its promise and protection to all manner of persons and peoples.

Today, various classes of rights are commonly distinguished. 17 The most typical distinctions are between:

1. subjective rights (those claimed by subjective individuals or groups or by parties who are subjects to an authority) versus objective right or rightness (conduct that is considered proper or orderly when measured against an objective standard),

2. natural rights (those that are based on nature, natural law, or human nature) and positive rights (those that are based in the positive law of the state, church, or other legal authority),

3. public or constitutional rights (those which operate vis-à-vis the state) and private or personal rights (those which operate vis-à-vis other private parties),

4. rights of individuals and rights of associations or groups (whether private groups, like businesses or churches, or public groups, like municipalities or political parties),

5. substantive rights (those that create or confirm goods or entitlements) and procedural rights (those that guarantee subjects certain types of treatment by government officials),

6. human rights (those that inhere in a human qua human) and civil rights (those that inhere in citizens or civil subjects),

7. unalienable or nonderogable rights (those that cannot be given or taken away) and alienable or derogable rights (those that can be voluntarily given away or can be taken away under specified legal conditions like due process of law),

8. will theories of rights (that emphasize the individual's rational choices and desires) and interest theories of rights (that focus on individual's needs and society's duties to meet those needs),

9. first generation civil and political rights, second generation social, cultural, and economic rights, and third generation rights to peace, environmental

16 See Samuel Moyn, The Last Utopia: Human Rights in History (Cambridge, MA: Harvard University Press, 2010); see further Samuel Moyn, "The Secret History of Constitutional Dignity," Yale Human Rights and Development Law Journal 17 (2014): 39-71.

17 See, among many others, W.N. Hohfeld, Fundamental Legal Conceptions as Applied in Judicial Reasoning, and Other Legal Essays (New Haven: Yale University Press, 1919); Carl Wellman, An Approach to Rights (Dordrecht and Boston: Kluwer Academic Publishers, 1997): Michael J. Perry, The Idea of Human Rights: Four Inquiries (New York: Oxford University Press, 1998); Joel Feinberg, Rights, Justice, and the Bounds of Liberty: Essays in Social Philosophy (Princeton, NJ: Princeton University Press, 1980); Maurice Cranston, "Human Rights, Real and Supposed," in Patrick Hayden, ed., The Philosophy of Human Rights (St. Paul, MN: Paragon House, 2001), 163-173; Joel Feinberg, "The Nature and Value of Rights," in ibid., 174-186; Thomas W. Pogge, "How Should Human Rights be Conceived?" in ibid., 187-211; Martha C. Nussbaum, "Capabilities and Human Rights," in ibid., 212-240. 
protection, and orderly development as they are called in international human rights law.

These different types of rights often correlate with different jural relationships. Some scholars distinguish between:

1. rights (something that triggers a correlative duty in others) and privileges (something that no one has a right to interfere with),

2. active rights (the power or capacity to do or assert something oneself) and passive rights (the entitlement or claim to be given or allowed something by someone or something else),

3. rights or privileges (claims or entitlements to something) and liberties or immunities (freedoms or protections from interference),

4. positive liberty or freedom (the right to do something) versus negative liberty or freedom (the right to be left alone).

These sundry rights distinctions have emerged over nearly two millennia of Western law - some more recently than others. Western jurists, since Roman law times, have talked quite easily about rights and liberties - iura and libertates as they were called in Latin, "ryhtes," "rihtes," and "rihta(e) as they came to be called in later Anglo-Saxon texts. 18 Jurists used rights language to define the law's protection, support, limitations, and entitlements of persons and groups in society, and to map the proper interactions between political and other authorities and their respective subjects. While Western jurists sometimes treated vaunted documents like the Magna Carta (1215)19 or the United States Bill of Rights (1791) with reverence, they usually thought of rights in simple instrumental and utilitarian terms. After all, as Justice Oliver Wendell Holmes, Jr. once put it, a right is "only the hypostasis of a prophecy," a mere prediction of what might happen to "those who do things said to contravene it." 20

By contrast, a number of Christian theologians and philosophers today are more hesitant about rights language. And some have engaged in heated debates and elaborate casuistry about the propriety of emphasizing subjective rights over objective right order, or personal liberties and entitlements over the moral virtues and duties of an eschatological faith.21 Yes, almost everyone acknowledges that Christians from the start embraced (subjective) religious rights, at least for the church and its members. And many Christians today lament the myriad persecutions of Christians and others around the world, 22 and the growing tension between religious freedom and sexual freedom in

18 See entry for "right" in Oxford English Dictionary, $2^{\text {nd }}$ ed. 20 vols. (Oxford: Oxford University Press, 1989); Alfred Kiralfky, "Law and Right in English Legal History," in La formazione storica de diritto moderno in Europa (Florence: Leo S. Olschki, 1977), 3:1069-1086.

19 See John Witte, Jr. "A New Magna Carta for the Early Modern Common Law: an $800^{\text {th }}$ Anniversary Essay," (herein).

20 Oliver Wendell Holmes, Jr., "Natural Law," Harvard Law Review 32 (1918): 40-44, at 42.

21 See esp. Nigel Biggar, "Imprudent Jurisprudence? Human Rights and Moral Contingency," (herein).

22 See Timothy Shah and Allen Hertzke, eds., Christianity and Freedom: Historical and Contemporary Perspectives (Cambridge: Cambridge University Press, 2016). 
the United States. 23 But many serious Christians today question seriously whether their spiritual predecessors really had much to do with rights, and whether modern human rights ideas faithfully express the moral norms and narratives of the Bible and the Christian tradition.24 These scholars call for better ideas and language to emphasize core virtues like faith, hope, and love and core goods like peace, order, and community.

How, then, does and should Christianity relate to human rights, and how do Christians today regard the monumental rights documents enacted fifty years ago? To address these questions, this journal symposium draws from the wisdom of six great scholars who explored these issues in their McDonald Distinguished Lectures on Law and Christianity at Emory University in March, 2014: Stanley Hauweras (Duke), Nigel Biggar (Oxford), Robert Franklin (Emory), Jean Porter (Notre Dame), Russell Hittinger (Tulsa), and Helen Alvare (George Mason). We have supplemented this collection with chapters by Archbishop Desmond Tutu and John Witte. The balance of this Introduction sets the story of Christianity and human rights in deeper historical context, and then maps some of the hard questions that challenge us today.

Together with our colleagues in the Center for the Study of Law and Religion at Emory University, we express our profound thanks to Ambassador Alonzo L. McDonald and his colleagues in the McDonald Agape Foundation for their generous support of this symposium issue and the McDonald Distinguished Scholar Lecture Series that lies behind it. This lecture series, which will run through 2018, is designed to sponsor cutting edge scholarship that stokes the imaginations of church, state, and society about what the Christian faith, in all its diversity, offers to the worlds of law, politics, and culture. We also wish to thank our Center colleagues, Amy Wheeler, Silas Allard, Anita Mann, Linda King, and Chris Manzer, for all their help with the lectures and with this symposium issue.

\section{The Contributions of Christianity to the Development of Western Rights}

Traditional Accounts of Subjective and Objective Rights. It might come as a surprise to some readers to learn that Christianity was a deep source of human rights in the Western legal tradition. Our elementary textbooks have long taught us that the history of human rights began in the later seventeenth and eighteenth centuries. Human rights, many of us were taught, were products of the Western Enlightenment creations of Grotius and Pufendorf, Locke and Rousseau, Montesquieu and Voltaire, Hume and Smith, Jefferson and Madison. Human rights were the mighty new weapons forged by American and French revolutionaries who fought in the name of political democracy, personal autonomy, and religious freedom against outmoded Christian

23 See the chapter by Helen Alvare, "Religious Freedom versus Sexual Expression: A Guide" (herein). 24 See, e.g., Stanley Hauerwas, "How to Think Theologically About Rights" (herein). For various constructive responses to such views, see Nicholas Wolterstorff, Justice in Love (Grand Rapids, Mich.: Wm. B. Eerdmans Publishing Co., 2011); Nicholas Wolterstorff, Justice Rights and Wrongs (Princeton: Princeton University Press, 2008); Timothy P. Jackson, Political Agape: Christian Love and Liberal Democracy (Grand Rapids, MI: Wm. B. Eerdmans Publishing Co., 2015). 
conceptions of absolute monarchy, aristocratic privilege, and religious establishment. Human rights were the keys that Western liberals finally forged to unchain themselves from the shackles of a millennium of Christian oppression of society and church domination of the state. Human rights were the core ingredients of the new democratic constitutional experiments of the later eighteenth century forward. The only Christians to have much influence on this development, we were told, were a few early Church Fathers who decried pagan Roman persecution, a few brave medieval writers who defied papal tyranny, and a few early modern Anabaptists who debunked Catholic and Protestant persecution. 25

Proponents of this conventional historiography have recognized that Western writers since classical Greek and Roman times often used the term "right" (ius in Latin, Recht in German, droit in French, diritto in Italian). But the conventional argument is that, before the Enlightenment, the term "right" was usually used in an "objective" rather than a "subjective" sense. "Objective right" or "rightness" means that something is the objectively right thing or action in the circumstances. Objective right obtains when something is rightly ordered, is just or proper, is considered to be right or appropriate when judged against some objective or external standard. "Right" is being used here as an adjective, not as a noun. It is what is correct or proper, the right way of doing and ordering things, following the norms taught to us by reason and conscience, nature and custom.26 As Oliver O'Donovan once put it: "'To give each his right' may include cutting off his head, if he has deserved it. 'Your right' is simply what is coming to you."27

This objective sense of right is quite different, the conventional argument continues, from the idea of right in a "subjective" sense - what is called a "subjective right." This is a right that is vested in a subject (whether an individual, group, or entity), and the subject usually can have that right protected or vindicated before an appropriate authority when the right is threatened or violated. The subjective and objective senses of right can cohere, even overlap. You can say that "a victim of theft has a right to have his property restored" or that "it is right for a victim of theft to have his property restored." Knowing nothing else, these are parallel statements. But if the victim is a ruthless tycoon and the thief a starving child, the parallel is harder to draw. Even though the subject (tycoon) has a subjective right to his property, it might not always be objectively right to respect or enforce that right. Sometimes the subjective and objective senses of right are more clearly dissociated. Even if it is objectively right for someone to perform an action, it does not always mean the beneficiary of that action has a subjective right to its performance. Though it might be right for you to give alms to the poor, a poor person has no subjective right to receive alms from you. Though it might be right for a parishioner to give tithes to the church, a church has no subjective right to

\footnotetext{
25 See representative literature analyzed in Victoria Kahn, "Early Modern Rights Talk," Yale Journal of Law and the Humanities 13 (2001): 391; Lynn Hunt, Inventing Human Rights: A History (New York: W.W. Norton, 2007); Samuel Moyn, "Substance, Scale, and Salience: The Recent Historiography of Human Rights," The Annual Review of Law and Social Science 8 (2012): 123-140.

26 See further Biggar, "Imprudent Jurisprudence?"

27 Oliver O'Donovan, "The Language of Rights and Conceptual History," The Journal of Religious Ethics 37 (June, 2009), 193-207, at 197.
} 
receive tithes from that parishioner.

When pre-seventeenth century writers spoke of the "rights" or "natural rights" of a person, the conventional argument goes, they were really referring to the "duties" of a person - the right thing for the person to do in accordance with natural order or natural law. As the great University of Chicago political philosopher and classicist, Leo Strauss, put it: "Natural right in its classic form is connected with a teleological view of the universe. All natural beings have a natural end, a natural destiny, which determines what kind of operation is good for them. In the case of men, reason is required for discerning these operations: reason determines what is by nature right with regard to man's natural end." 28

Enlightenment philosophers, beginning with Thomas Hobbes and John Locke, Strauss continued, first began to use the term "right" or "natural right" in a subjective rather than an objective sense. For the first time in the later seventeenth century, the term "right" was regularly used as a noun not as an adjective. A "subjective right" was now viewed as a claim, power, or freedom which nature had vested in a subject, whether a person or entity. If that subject's right was threatened or violated, they could go to an appropriate authority to have that right vindicated. The establishment of this subjective understanding of rights was the start to the modern discourse of human rights, we are told. When Enlightenment figures spoke of "natural rights" or the "rights of man according to natural law," they were increasingly describing what we usually mean by "rights" today - the inherent claims that the individual subject has to various natural goods like life, liberty, and property. This was "an entirely new political doctrine," writes Strauss. "The premodern natural law doctrines taught the duties of man; if they paid any attention at all to his rights, they conceived them as essentially derivative from his duties. As has been frequently observed, in the course of the seventeenth and eighteenth centuries a much greater emphasis was put on rights than ever had been before. One may speak of a shift of emphasis from natural duties to natural rights." 29

Strauss's full historical account of rights is much more nuanced than this, as are the later historical accounts of some of his best students who have found some place for earlier theories of subjective rights. 30 Moreover, it must be remembered that Strauss himself (and some of his students) wrote their histories of rights in part to decry the unhinging of objective and subjective rights, and the consequent decay of modern right talk into a long subjective wish list of goods that had no objective basis. And Strauss himself in some of his later writings spent a good deal of time mining the rich teachings

28 Leo Strauss, Natural Right and History (Chicago: University of Chicago Press, 1953), 7.

29 Ibid., 182. See further id., The Political Philosophy of Hobbes: Its Basis and its Genesis, trans. Elsa Sinclair (Chicago: The University of Chicago Press, 1952); id., What is Political Philosophy? And Other Studies (Glencoe, IL: The University of Chicago Press, 1959), esp. 197ff.

30 See, esp. Michael P. Zuckert, The Natural Rights Republic: Studies in the Foundation of the American Political Tradition (Notre Dame: University of Notre Dame Press, 1996); id., Natural Rights and the New Republicanism (Princeton: Princeton University Press, 1994); id., Launching Liberalism: On Lockean Political Philosophy (Lawrence, KS: University Press of Kansas, 2002). 
of his own ancient tradition of Judaism. 31 But, particularly when cast into popular secular form, as it usually is, this basic "Straussian" account of the Enlightenment origins of Western rights has persisted, with numerous variations, in many circles of discourse to this day.

Those circles of discourse include Christianity. As noted above, a number of Christians today - Catholic, Orthodox, and Protestant alike - view human rights with suspicion, if not derision. Many view human rights as a dangerous invention of Enlightenment liberalism, predicated on a celebration of reason over revelation, of greed over charity, of nature over Scripture, of the individual over the community, of the pretended sovereignty of man over the absolute sovereignty of God. 32 Others view human rights as a tried and tired experiment that is no longer effective, even a fictional faith whose folly has now been fully exposed 33 - "nonsense upon stilts," as Jeremy Bentham once called it.34 Others view human rights as instruments of neo-colonialism

31 Leo Strauss, Jewish Philosophy and the Crisis of Modernity: Essays and Lectures in Modern Jewish Thought, ed. Kenneth H. Green (Albany, NY: State University of New York Press, 1997).

32 This is the position often associated with the great Swiss Reformed theologian, Karl Barth. See detailed sources in the recent study by Stephen J. Grabill, Rediscovering the Natural Law in Reformed Theological Ethics (Grand Rapids, MI: Wm. B. Eerdmans Pub. Co., 2006), 21-53. While Barth was certainly opposed to much natural theology, natural law, and natural rights talk, he was not so adverse to human rights as he is often made out to be. For example, as a pastor in Safenwil he worked hard to secure the rights of workers and unions, the right to secure better wages and working conditions, the right to secure a job that satisfied one's calling and that confirmed one's "human dignity." As a Christian socialist, he was a fierce advocate for the rights of the poor, the widow, the orphan, the sojourner. As he put it: "God always stands on this and only on this side, always against the exalted and for the lowly, always against those who already have rights and for those from whom they are robbed and taken away." And as principal author of the courageous 1934 Barmen Declaration against Nazism, Barth gave vivid new expression to the founding rights of the Calvinist tradition - the right to religious liberty and the right of religious leaders prophetically to condemn tyrants who abridge these first rights to religion. See sources quoted and analyzed in George Hunsinger, "Karl Barth," in John Witte, Jr. and Frank S. Alexander, eds., Modern Christian Teachings on Law, Politics, and Human Nature, 2 vols., (New York, 2005), 1:352-380, 2:280-306.

33 See, e.g., Alasdair Maclntyre, After Virtue: A Study in Moral Theory (Notre Dame: University of Notre Dame Press, 1984), 69-70. Macintyre writes: "[T]he truth is plain: there are no such rights, and belief in them is one with belief in witches and in unicorns....Natural or human rights...are fictions." See also John Milbank's discussion of "dignity" and "rights" in political philosophy and Catholic moral theology in "Dignity Rather than Right," Centre of Theology and Philosophy, Accessed February 11, 2015,

http://theologyphilosophycentre.co.uk/papers/Milbank_DignityRatherThanRight.pdf. Also see, from a nonreligious perspective, Richard Rorty, "Human Rights, Rationality, and Sentimentality" in Patrick Hayden, ed., Philosophy of Human Rights (St. Paul, MN: Paragon House, 2001), 241-257.

34 Jeremy Bentham, "Anarchical Fallacies; Being an Examination of the Declaration of Rights issued during the French Revolution," reprinted in Jeremy Waldron, ed., Nonsense Upon Stilts: Bentham, Burke and Marx on the Rights of Man (New York: Methuen, 1987), 53. The passage from which this phrase is taken reads: "That which has no existence cannot be destroyed - that which cannot be destroyed cannot require anything to preserve it from destruction. Natural rights is simple nonsense: natural and imprescriptible rights, rhetorical nonsense, - nonsense upon stilts. But this rhetorical nonsense ends in the old strain of mischievous nonsense: for immediately a list of these pretended natural rights is given, and those are so expressed as to present to view legal rights. And of these rights, whatever they are, there is not, it seems, any one of which any government can, upon any occasion whatever, abrogate the smallest particle." 
which the West uses to impose its values on the rest. 35 Still others view rights talk as the wrong talk for deep and meaningful debate about questions of human dignity, social justice, peaceful order, and the common good. 36 Duke University's Übertheologian, Stanley Hauweras, has voiced powerful reservations about treating human rights as a heuristic for Christian morality, and he summarizes his case in the pages that follow, answering some of his critics along the way. 37 Other Christian scholars share this skepticism, including leading Anglican moral theologian, Oliver O'Donovan, 38 distinguished Catholic philosopher, Alasdair McIntyre,39 Orthodox Ecumenical Patriarch Bartholomew, 40 and scores of mainline Protestant and Evangelical scholars influenced by Karl Barth's early "Nein!" to natural law and natural rights talk.41 Distinguished Oxford theologian and ethicist, Nigel Biggar, engages this literature deftly and critically in his contribution to this symposium. 42

At a certain level of abstraction, these Christian critiques of the moral and theological propriety of human rights mirror Straussian accounts of the Enlightenment origins of rights. Various Straussians dismiss pre-modern Christian rights talk as a betrayal of Enlightenment liberalism. Various Christians dismiss modern Enlightenment rights talk as a betrayal of Christianity.

Whatever the philosophical and theological merits of these respective positions might be, the historical narratives that have long supported them are no longer tenable. A growing body of important new scholarship has emerged to demonstrate that the Enlightenment was not so much a well spring of Western rights as a watershed in a long stream of rights thinking that began more than two millennia before. A comprehensive history of Western rights is still very much a work in progress, with serious scholars still discovering and disputing the basic roots and routes of development. But a broad outline of the story of the development of Western rights is becoming clearer. And in this historical narrative, biblical, Roman law, medieval Catholic, and early modern

35 See critical discussion in David Little, "Rethinking Human Rights: A Review Essay on Religion, Relativism, and Other Matters," Journal of Religious Ethics 27 (Spring 1999), 151-177.

36 See Mary Ann Glendon, Rights Talk: The Impoverishment of Political Discourse (New York: Free Press, 1991); Marta Cartabia, "Europe and Rights: Taking Dialogue Seriously," European Constitutional Law Review 5 (2009).

37 See, e.g., Stanley Hauerwas, "The Hauerwas Reader (Durham, NC/London: Duke University Press, 2001), 51-74, 577-622.

38 O'Donovan, "The Language of Rights and Conceptual History."

39 See Maclntyre, After Virtue; also see Alasdair Maclntyre, "How to Identify Ethical Principles" at http://videocast.nih.gov/pdf/ohrp_appendix_belmont_report_vol_1.pdf (Accessed February 12, 2015).

40 See John Witte, Jr. and Michael Bourdeaux, eds., Proselytism and Orthodoxy in Russia: The New War for Souls (Maryknoll, NY: Orbis Books, 1999), 19-20. See a good summary of Orthodox rights skepticism, summarized and answered in John McGuckin, The Ascent of Christian Law: Patristic and Byzantine Formulations of a New Civilization (Yonkers, NY: St. Vladimir's Seminary Press, 2012).

41 Karl Barth, Nein! Antwort an Emil Brunner (Munich: C. Kaiser, 1934). For an English translation see Karl Barth and Emil Brunner, Natural Theology: Comprising 'Nature and Grace' (Eugene, OR: Wipf and Stock, 2002). For a recent example, see James Hutson, Forgotten Features of the Founding Era: The Recovery of Religious Themes in the Early American Republic (Lanham, MD: Lexington Books, 2003), 73-110.

42 Biggar, "Imprudent Jurisprudence?" 
Protestant Christian sources, among others, were just as important to the development of rights as modern Enlightenment liberalism. 43 Here's a short summary of what we now know.

Biblical Foundations. The Bible has long been used as the anchor text for Christian teachings on human rights. The Bible is no human rights textbook, of course. 44 But both the Hebrew Bible and the New Testament are filled with critical passages that have long inspired deep insights into the origin, nature, and purpose of human rights.

Foremost among the Hebrew Bible texts is the Genesis account of the creation of man and woman. Genesis 1 rehearses God's creation of the world, and then comes to the apex:

Then God said, "Let us make man in our image, after our likeness; and let them have dominion over the fish of the sea, and over birds of the air, and over the cattle, and over all the earth, and over every creeping thing that creeps upon the earth." So God created man in his own image, in the image of God he created him; male and female he created them. And God blessed them, and God said to them, "Be fruitful and multiply, and fill the earth and subdue it; and have dominion over the fish of the sea and over the birds of the air and over every living thing that moves upon the earth." 45

Archbishop Desmond Tutu's contribution to this symposium underscores how the idea of humans created in the image of God forms the deep ontological foundation of a Christian theory of human dignity, human freedom, and human rights. Every human being is created as a "God-carrier," Tutu writes, and as such deserves the utmost respect of his or her neighbors because of that inherent dignity. 46 Every human being is created with reason, will, and conscience, and has the inherent right and duty to make choices guided by the law written on their hearts and rewritten in Scripture, tradition, and experience. Tutu puts it memorably: "God, who alone has the perfect right to be a

43 See recent overviews in Fabian Wittreck, Christentum und Menschenrechte (Tübingen: Mohr Siebeck, 2013); Michael Welker, ed., Quests for Freedom: Biblical - Historical - Contemporary (Göttingen:

Neukirchen, 2015); John Witte, Jr. and Frank S. Alexander, eds., Christianity and Human Rights: An Introduction (Cambridge: Cambridge University Press, 2010); Johannes van der Ven, Human Rights or Religious Rules? (Leiden: Brill, 2010).

44 Various scholars, however, have drawn many rights and related doctrines on the strength of the Bible. See, e.g., Jonathan Burnside, God, Justice, and Society: Aspects of Law and Legality in the Bible (New York: Oxford University Press, 2011); Robert F. Cochran and David VanDrunen, eds., Law and Bible: Justice, Mercy and Legal Institutions (Downers Grove, IL: InterVarsity Press, 2013); Brent A. Strawn, et al eds., The Oxford Encyclopedia of the Bible and Law, 2 vols. (New York: Oxford University Press, 2015); Richard H. Hiers, Women's Rights and the Bible: Implications for Christian Ethics and Social Policy (Eugene, OR: Pickwick Publications, 2012); David Novak, Covenantal Rights: A Study in Jewish Political Theory (Princeton: Princeton University Press, 2000).

45 Gen. 1:26-28 (Revised Standard Version).

46 Desmond M. Tutu, "The First Word: to be Human is to be Free" (herein). 
totalitarian, has such a profound reverence for our freedom that He had much rather we went freely to hell than compel us to go to heaven." 47

The creation story continues with God's command to the first man and the first woman to join together "in one flesh" and to "be fruitful and multiply." 48 This primal teaching about the first family was amplified in many later biblical passages that modeled marriage on Yahweh's enduring love for his chosen people,49 and Christ's eternal love for his church50 and that called parents and their broader kin networks to tend to the nurture, care, and education of children. These biblical passages provided Jews and Christians alike with foundations on which to build their systems of family law, and the attendant special rights and duties afforded to spouses, parents, children, and kin. 51

The creation story ends by recounting that humans are called to be caretakers and cultivators of nature, tasked to "dress" and "keep" the beauties of the Garden of Paradise even as they build toward the splendors of a Golden City in the eschaton.52 In this primal command of stewardship, medieval monks and modern Christian environmentalists alike have found the warrants for what we now call the third generation rights of nature and of orderly and sustainable development.53

Also fundamental to later Christian teachings were the many reciprocal rights and duties embedded in the 613 commandments of the Mosaic law and their amplification both by the Prophets of the Hebrew Bible and the Rabbis of the Talmud.54 This early Judaic understanding of rights and duties inspired the Church Fathers, medieval Catholics, and early modern Protestants alike. Particularly, the two tables of the Ten Commandments set out in Exodus 20 and Deuteronomy 5 proved important to later Christian rights theorists. The First Table of the Decalogue set out the basic religious duties to honor, worship, and properly use God's name. The Second Table set out the

47 Ibid.

48 Gen. 1:28 (RSV).

49 See biblical texts cited in John Witte, Jr., "The Covenant of Marriage: Its Biblical Roots, Historical Influence, and Modern Uses," INTAMS review. Journal for the Study of Marriage and Spirituality 18 (2012), 147-165.

50 Eph. 5:32.

51 See John Witte, Jr., From Sacrament to Contract: Marriage, Religion and Law in the Western

Tradition, second ed., (Louisville, KY: Westminster John Knox Press, 2012).

52 Gen. 2:15 (RSV).

53 For related perspectives on the Bible, Christianity, and environmental issues, see: Bron Taylor, ed., The Encyclopedia of Religion and Nature (New York: Oxford University Press, 2010); John Chryssavgis and Bruce v. Foltz, eds., Toward an Ecology of Transfiguration: Orthodox Perspectives on Environment, Nature, and Creation (New York: Fordham University Press, 2013); Noah J. Toly and Daniel I. Block, eds., Keeping God's Earth: The Global Environment in Biblical Perspective (Downers Grove, IL:

InterVarsity Press, 2010); Willis J. Jenkins, Ecologies of Grace: Environmental Ethics and Christian Theology (Oxford and New York: Oxford University Press, 2008); John Copeland Nagle, "A Right to Clean Water," in Witte and Alexander, eds. Christianity and Human Rights, 335-350; Willis Jenkins, "Religion and Environmental Rights," in ibid., 330-345.

54 David Novak, "The Judaic Foundations of Rights," in John Witte, Jr. and Frank S. Alexander, eds., Christianity and Human Rights: An Introduction (Cambridge: Cambridge University Press, 2010), 47-63. 
basic duties concerning marriage, family, and the household, life, property, and reputation. While the Decalogue sets out the duties owed to God and neighbors, later Christian writers used this template to set out the correlative religious rights to godly worship and honor, and the correlative civil rights to life, property, reputation, and the marital household. 55

The Mosaic law governed a "covenanted" people who were bound together in community with each other and with God.56 Already with Noah in the aftermath of the Flood, the Bible tells us, God had entered into a covenant with all humanity and nature. 57 Both Jews and Christians would later see in this Noahide covenant the foundation of a natural law and natural rights order.58 Thereafter God entered into a more particular covenant with the chosen people of Israel, repeating the terms of the covenant to their leaders, Moses, Joshua, Hezekiah, Josiah, and Ezra.59 This covenant obliged every member of the community to love and care for their neighbors, to see to their protection and welfare, to help them achieve a good life. As Chief Rabbi Lord Jonathan Sacks has written, the "fate" of a covenant community "is dependent on its treatment of the most vulnerable and marginal members. Ultimately, how a society fares in history is dependent on its commitment to justice, to compassion, to caring for the poor and the widow and the orphan and the stranger."60 The later Prophets of the Hebrew Bible returned to these themes repeatedly in calling the people of Israel to their covenant obligations. Many later Christian scholars would use these Old Testament passages and their echoes in the New to defend the rights of the poor, needy, children, widows, orphans, and sojourners. 61

The New Testament offers several strong pronouncements on freedom. "For freedom, Christ has set us free." "You were called to freedom." "Where the Spirit of the Lord is, there is freedom." "For the law of the Spirit of life in Christ has set [you] free from the law of sin and death." "You will know the truth, and the truth will make you free." "You will be free indeed." You all have been given "the law of freedom" in Christ, "the glorious liberty of the children of God." You must all now "live as free men." 62 These passages have long inspired Christians to work out the meaning and means of

55 See John Witte, Jr., The Reformation of Rights: Law, Religion, and Human Rights in Early Modern Calvinism (Cambridge: Cambridge University Press, 2007).

56 See, e.g., Daniel J. Elazar, Covenant and Polity in Biblical Israel: Biblical Foundations and Jewish Expressions (New Brunswick, NJ: Transaction Publishers, 1995); Novak, Covenantal Rights

57 Gen. 9:1-17.

58 See David Novak, Natural Law in Judaism (Cambridge and New York: Cambridge University Press, 1998); David VanDrunnen, Divine Covenants and Moral Order: A Biblical theology of Natural Law (Grand Rapids, MI: Wm. B. Eerdmans Publishing Co., 2014).

59 See Deuteronomy 29-31; Joshua 24; 2 Chronicles 29 and 34; 2 Kings 22-23; Nehemiah 8.

60 Jonathan Sacks, "The Great Covenant of Liberties: Biblical Principles and Magna Carta," in Robin Griffith-Jones and Mark Hill QC, eds., Magna Carta, Religion, and the Rule of Law (Cambridge:

Cambridge University Press, 2015), ms. p. 7

61 See, e.g., George M. Newlands and Allen P. Smith, Hospitable God: The Transformative Dream (Burlington, VT: Ashgate, 2010); George M. Newlands, Christ and Human Rights: The Transformative Engagement (Burlington, VT: Ashgate, 2006).

62 Rom. 8:2, 21; John 8:32, 36, 1 Pet. 2:16. 
attaining spiritual and political freedom. Already in the first centuries after Christ, the Church Fathers and church councils used these texts as the foundation for its increasingly detailed canon laws that defined Christian responsibility within the church, and shaped its rallying cries for liberty within the state. In later centuries, Catholic, Protestant, and Orthodox Christians alike turned to these biblical texts as starting points for their theories of rights and liberties.

The New Testament also calls for equality. St. Paul's manifesto to the Galatians famously declares: "There is neither Jew nor Greek, there is neither slave nor free, there is neither male nor female; for you are all one in Christ Jesus."63 This radical Christian message of human equality trumped conventional Graeco-Roman hierarchies based on birth, nationality, social status, gender, and more. St. Peter amplified this call to equality with his admonition that all Christian believers are called to be prophets, priests, and kings of God: "You are a chosen race, a royal priesthood, a holy nation, God's own people."64 These New Testament passages were critical to the gradual development of the understanding of equal protection and treatment of all persons before the law, and to domestic and international guarantees of freedom of all from discrimination based on gender, race, culture, ethnicity, and social or economic status.

The New Testament was even more radical in its call to treat the "least" members of society with love, respect, and dignity. Jesus took pains to minister to the social outcasts of his day - Samaritans, tax collectors, prostitutes, thieves, traitors, lepers, the lame, the blind, the adulteress, and others. 65 "He who is without sin, cast the first stone," he instructed a stunned crowd ready to stone a convicted adulteress.66 "Today you will be with me in Paradise," he told the contrite thief nailed on the cross next to his. 67 Even the duly convicted criminal deserves mercy and love was the point. Echoing the Hebrew Bible, Jesus called his followers to feed and care for the poor, widows, and orphans in their midst, to visit and comfort the sick, imprisoned, and refugee. "Whatever you do for one of the least of these brothers of mine, you do for me," he told them.68 And Jesus paid special attention to the care, nurture, and protection of children, and warned that it would be better to be cast in a sea with a millstone around one's neck than to mislead a child. Few texts in the day would prove stronger foundation for the later development of children's rights in the Christian tradition. 69

63 Gal. 3:26-28; see also Col. 3:11, Eph. 2:14-15.

64 I Peter 2:9; cf. Revelation 5:10, 20:6.

65 See, e.g., Luke 10:25-37; Matthew 9:10; Luke 7:36-50; Matthew 21:31; Mark 15:27; Matthew 8:3; Mark 2:1-12; Mark 8:22-25; John 8:1-15.

66 John $8: 7$

67 Luke 23:43

68 Matt. 25:40

69 See Marcia Bunge, Children in the Bible (Grand Rapids, MI: Wm. B. Eerdmans Publishing Co., 2008); Marcia Bunge, ed., The Child in Christian Thought (Grand Rapids, MI: Wm. B. Eerdmans Publishing Co., 2001); John Witte, Jr. and Don S. Browning, "Christianity's Mixed Contributions to Children's Rights:

Traditional Teachings, Modern Doubts," 61 Emory Law Journal 991 (2011-2012), 991-1014; Symposium, "What's Wrong With Rights for Children?" Emory International Law Review, 20 (2006): 1-239. 
Jesus and St. Paul also called believers to share their wealth, to shore up those in need, to give up their extra clothes and belongings even to their creditors. 70 They even called believers to love their enemies, 71 to give them food and water, 72 to turn their cheeks to those who strike them, 73 to forgo lawsuits, vengeance, and retributive measures, 74 to be peacemakers in expression of the radical demands of Christian discipleship. 75 Many Christians over the centuries - monks and nuns, ascetics and Anabaptists, missionaries and peacemakers and various others - have sought to live out these Christian ideals, often in highly structured Christian communities. These biblical passages and historical exemplars, too, provide strong foundations for the rights of the poor and needy in society. 76

Finally, the New Testament called Christians to "render to Caesar the things that are Caesar's and to God the things that are God's"77 and reminded them that God has appointed "two swords" 78 to rule this life, the spiritual and the temporal. It called believers to "remain separate" from worldly temptations, to be "in the world, but not of it," and not "conformed" to its secular ways.79 For Christians are, at heart, "strangers and foreigners on the earth"; their "true citizenship is in heaven." 80 The Bible also spoke frequently about building and rebuilding "walls" to foster this basic separation between believers and the outside world. In the Hebrew Bible, these walls separated the City of Jerusalem from the outside world, and the temple and its priests from the commons and

70 See, e.g., Mark 10:13-16; Matthew 19:13-15; Mark 7:24-30; Mark 9:14-27; John 4:46-52; Luke 8:4056; Matt. 18:5-9.

71 Matt. 5:43-48.

72 Matt. 25:31-46.

73 Matt. 5:38-40.

74 Matthew 5:25.

75 Matt. 5:21-26; Rom. 12:9-21.

76 See Tutu, "To be Human is to be Free," (herein). In the vast literature, see, e.g., Brian Tierney, Medieval Poor Law: A Sketch of Canonical Theory and its Application in England (Berkeley: University of California Press, 1959); Walter Rauschenbusch, A Theology for the Social Gospel (Louisville, KY: Westminster John Knox Press, 1997); Martin Luther King, Jr., A Testament of Hope: The Essential Writings of Martin Luther King, Jr., James M. Washington, ed., (San Francisco: Harper \& Row, 1986); United Stated Catholic Bishops, Economic Justice for All: Pastoral Letter on Catholic Social Teaching and the U.S. Economy (1986), last accessed February 13, 2015,

http://www.usccb.org/upload/economic_justice_for_all.pdf); Leo XIII, Rerum Novarum [On Capital and Labor], 1891; Vatican Council II, "Gaudium et Spes [Pastoral Constitution on the Church in the Modern World]", 1965; Paul VI, Populorum Progressio [On the Development of Peoples], 1967; etc. The papal encyclicals, etc. cited above are available on the Vatican website, http://w2.vatican.va/content/francesco/en/encyclicals/index.html.

77 Matt. 22:21; Mark 12:17; Luke 20:25.

78 Luke 22:38.

792 Cor. 6:17; Romans 12:2

80 Heb. 11:13; Rom. 12:2; 2 Cor. 6:14-18; Col. 3:1; Phil. 3:20. As one second-century Christian writer explained, for Christians "any foreign country is a motherland, and any motherland is a foreign country." See Maxwell Staniforth (trans.), Betty Radice (ed.), "The Epistle to Diognetus," in Early Christian Writings: The Apostolic Fathers, (Baltimore, MD: Penguin Books, 1968), 176. 
its people.81 In the New Testament, St. Paul spoke literally of a "wall of separation." 82 These passages and others have inspired Christians over the centuries to develop dualistic theories of religion and politics, church and state - two ways, two cities, two powers, two swords, two kingdoms, two realms, and two institutions of religion and politics, of spiritual and temporal life. Today such images are captured in constitutional injunctions to separate church and state, and to protect the rights and autonomy of churches and their leadership. 83

Classical Roman Law. While the Bible provided ample inspiration for the later development of rights in the West, classical Roman law provided ample illustration of how rights worked in a sophisticated legal system. 84 Both before and after the Christian conversion of Emperor Constantine in the fourth century CE, classical Roman jurists used the Latin term "ius" to identify a "right" in both its objective and subjective senses. (lus also meant law or legal order more generally). The objective sense of ius - to be in proper order, to perform what is right and required, "to give to each his due" (ius suum cuiuque tribuere) - dominated the Roman law texts. But these texts also sometimes used ius subjectively, in the sense of a person having a right that could be defended and vindicated. Many of the subjective rights recognized at classical Roman law involved property: the right to own or co-own property, the right to possess, lease, or use property, the right to build or prevent building on one's land, the right to gain access to water, the right to be free from interference with or invasion of one's property, the right or capacity to alienate property, the right to bury one's dead, and more. Several texts dealt with personal rights: the rights of testators and heirs, the rights of patrons and guardians, the rights of fathers and mothers over children, the rights of masters over slaves. Other texts dealt with public rights: the right of an official to punish or deal with his subjects in a certain way, the right to delegate power, the right to appoint and supervise lower officials. Others dealt with procedural rights in criminal and civil cases. Leading Harvard legal historian, Charles Donahue, has recently identified 191 texts on subjective rights in the Digest alone (one of the four books of Justinian's sixth-century Corpus luris Civilis) and speculates that hundreds if not thousands more such texts can be found in other books of classical Roman law. 85

The classical Roman law also referred to subjective rights using the Latin term "libertas," which translates variously as liberty, freedom, privilege, or independence. At its most basic level, libertas was, as Justinian put it, "the natural ability (facultas) to do

811 Kings 3:1; Jeremiah 1:18-19, 15:19-21; Ezekiel 42:1; Nehemiah 3:1- 32, 4:15-20, 12:27-43.

82 Eph. 2:14.

83 See John Witte, Jr., "Facts and Fictions About the History of Separation of Church and State," 48 Journal of Church and State 15 (2006), 15-46.

84 For this section, see especially the sources and discussion in Charles A. Donahue, "lus in the Subjective Sense in Roman Law: Reflections on Villey and Tierney," in Domenico Maffei, ed., A Ennio Cortese, 3 vols. (Rome: Il Cigno Ed., 2001), 1:506-535; Max Kaser, lus Gentium (Cologne: Böhlau, 1993); id., Ausgewählte Schriften, 3 vols. (Naples: Jovene, 1976-1977); Tony Honoré, Ulpian: Pioneer of Human Rights, 2d ed. (Oxford and New York: Oxford University Press, 2002); C. Wirszubski, Libertas as a Political Idea at Rome During the Late Republic and Early Principate (Cambridge: Cambridge University Press, 1950).

85 Charles Donahue, "Ius in the Subjective Sense in Roman Law," supra. 
anything one pleases, unless it is prohibited by force or law."86 One's libertas at Roman law turned in part on one's status in Roman society. Men had more libertas than women, married women more than concubines, adults more than children, citizens more than non-citizens. But each person at Roman law had a basic libertas inherent in his or her social status. This included a basic right to be free from subjection or undue restraint or actions from others who had no right (ius) to or possessory claim (dominium) over them. Think of St. Paul who claimed the libertas of a Roman citizen to be free from whipping or capital punishment without a hearing before the emperor who alone had such ultimate authority over him.87 Similarly, a wife had libertas from sexual relations with all others besides her husband. A natural or adopted child had libertas from the discipline of all others save his or her parents and paterfamilias. Even a slave had libertas from the discipline of others besides the master and his delegates. And those rights could be vindicated by filing actions against the offender before a praetor, judge (iudex), or other authority, directly or, as was more typical for those in lower social stations, through a representative.

Some libertas interests recognized at Roman law were cast more generally, and were not necessarily conditioned on the correlative duties of others. A good example was the freedom of religion guaranteed to Christians and others under the Edict of Milan (313) passed by Emperor Constantine. This included "the freedom (libertas) to follow whatever religion each one wished"; "a public and free liberty to practice their religion or cult"; and a "free capacity" (facultas) to follow their own religion "and worship as befits the peacefulness of our times." 88

Medieval Catholicism. While some Germanic, canonical, and penitential texts of the later first millennium echoed these Roman rights discussions, the rediscovery and new study of Roman law texts in the late eleventh century forward helped to trigger a renaissance of subjective rights talk in the West. Leading medievalist, Brian Tierney, has shown that, already in the twelfth century, the civilians and canonists (the jurists who worked on the church's laws, which were called canon laws) differentiated all manner of rights (iura) and liberties (libertates).89 They grounded these rights and liberties in the law of nature (lex naturae) or natural law (ius naturale), and associated them variously with a power (facultas) inhering in rational human nature, with the property (dominium) of a person, or the power (potestas) of an office of authority (officium). The early canonists repeated and glossed many of the subjective rights and liberties set out in Roman law - especially the public rights and powers of rulers, the

86 Justinian, Institutes, I.III. See English translation in Peter Birks and Grand McLeod, eds., Justinian's Institutes (Ithaca, NY: Cornell University Press, 1987).

87 Acts 22:22-29.

88 See Sidney Ehler and John Morrall, Church and State through the Centuries: A Collection of Historic Documents with Commentaries (Westminster, MD: Newman Press, 1954), 4-6, original in Lactantius, De Mortibus Persecutorum [c. 315], 48.2-12, ed. and trans. J. L. Creed (Oxford and New York: Clarendon Press, 1984), 71-73.

89 For this section, see Brian Tierney, The Idea of Natural Rights: Studies on Natural Rights, Natural Law, and Church Law, 1150-1625 (Grand Rapids, MI: Wm. B. Eerdmans, 2001); see further Peter Landau, "Zum Ursprung des 'lus ad Rem' in der Kanonistik," in Proceedings of the Third International Congress of Medieval Canon Law (1971): 81-102. 
private rights and liberties of property, and what the great canonist Gratian in ca. 1140 called the "rights of liberty" (iura libertatis) enjoyed by persons of various stations in life and offices of authority. 90 The canonists also began to weave these early Roman law texts into a whole complex latticework of what we now call rights, freedoms, powers, immunities, protections, and capacities for different groups and persons. 91

Most important to the medieval canonists were the rights needed to protect the "freedom of the church" (libertas ecclesiae). "Freedom of the Church" from civil and feudal control and corruption was the rallying cry of Pope Gregory VII that inspired the Papal Revolution of 1075 and ultimately established the church as an independent legal and political authority for all of Western Christendom.92 In defense of this revolution, medieval canonists specified in great detail the rights of the church to make its own laws, to maintain its own courts, to define its own doctrines and liturgies, to elect and remove its own clergy. They stipulated the exemptions of church property from civil taxation and takings, and the right of the clergy to control and use church property without interference or encumbrance from secular or feudal authorities. They guaranteed the immunity of the clergy from secular prosecution, military service, and compulsory testimony; and the rights of church entities like parishes, monasteries, charities, and guilds to form and dissolve, to accept and reject members, and to establish order and discipline. They defined the rights of church councils and synods to participate in the election and discipline of bishops, abbots, and other clergy. They defined the rights of the lower clergy vis-à-vis their superiors. They defined the rights of the laity to worship, evangelize, maintain religious symbols, participate in the sacraments, travel on religious pilgrimages, and educate their children. They defined the rights of the poor, widows, and needy to seek solace, succor, and sanctuary within the Church. They defined the rights of husbands and wives, parents and children, masters and servants within the household. They defined the (truncated) rights that Orthodox Christians, Jews, Muslims, and heretics had in Christian society. These medieval canon law rights and liberties were enforced by a hierarchy of church courts and other administrative church offices, each with distinctive and complex rules of litigation, evidence, and judgment, and each providing the right to appeal, ultimately to Rome. 93

90 C. 16 , q. 3, dictum post c. 15, as quoted in Tierney, Idea of Natural Rights, 57.

91 See R.H. Helmholz, The Privilege Against Self-Incrimination: Its Origins and Development (Chicago: University of Chicago Press, 1997); James Q. Whitman, The Origins of Reasonable Doubt: Theological Roots of the Criminal Trial (New Haven: Yale University Press, 2008).

92 Harold J. Berman, Law and Revolution: The Formation of the Western Legal Tradition (Cambridge, MA: Harvard University Press, 1983).

93 Tierney, Idea of Natural Rights, supra.; id., Rights, Law, and Infallibility in Medieval Thought (Aldershot, Hampshire, and Brookfield, VT: Variorum, 1997); id., Religion, Law, and the Growth of Constitutional Thought, 1150-1650 (Cambridge and New York: Cambridge University Press, 1982); Udo Wolter, "Amt und Officium in mittelalterlichen Quellen vom 13. bis 15. Jahrhundert: Ein begriffsgeschichtliche Untersuchung," ZSS KA 78 (1988): 246; Charles J. Reid, Jr., "Rights in Thirteenth Century Canon Law: An Historical Investigation" (Ph.D. Diss. Cornell, 1994); id., "Thirteenth Century Canon Law and Rights: The Word ius and its Range of Subjective Meanings," Studia Canonica 30 (1996): 295; id., Jr., "Roots of a Democratic Church Polity in the History of the Canon Law," Canon Law Society of America Proceedings 60 (1998): 150; id., Power Over the Body, Equality in the Family: Rights and Domestic Relations in Medieval Canon Law (Grand Rapids, 2004); James Muldoon, "The Great 
These rights formulations yielded increasingly sophisticated reflections in the writings not only of medieval jurists, but also of medieval theologians and philosophers. Distinguished Notre Dame ethicist, Jean Porter, shows in her contribution herein that the great thirteenth-century Dominican sage, Thomas Aquinas, embraced subjective rights in part, drawing together insights from Aristotle, the Church Fathers, Roman law, and canon law. Aquinas did not develop a full blown theory of subjective rights, nor did he generally refer to someone's right in possessory terms, or as discrete moral powers. Yet Porter shows that, for Aquinas, certain appeals to justice did not merely invoke an objective order of mutual obligations. For Aquinas, Porter writes, a moral agent "possesses a general moral power for self-determining action, which she can exercise preemptively on the basis of some claim of right."94 Even if Thomas's right talk remained rudimentary and scattered, there were ever fuller subjective rights discussions among rival nominalist philosophers like John Duns Scotus and William of Ockham as

Commission and the Canon Law," in Sharing the Book: Religious Perspectives on the Rights and Wrongs of Proselytism, ed. John Witte, Jr. and Richard C. Martin (Maryknoll, NY: Orbis Books, 1999), 158.

94 Jean Porter, "Justice, Equality, and Natural Rights Claims: A Reconsideration of Aquinas' Conception of Right," (herein) [quote is taken from concluding paragraph] 
well among later medieval sages like Marsilius of Padua, John Wycliffe, Conrad Summenhart, Richard Fitzralph, Jean Gerson, and others. These high and later medieval rights discussions were synthesized and greatly expanded in the brilliant writings of the Spanish jurists, theologians, and philosophers gathered at the University of Salamanca - Francisco de Vitoria, Fernando Vázquez, Francisco Suarez, Bartolomé de las Casas, and many others. 95 Vitoria, in particular, made path-breaking advances in defending "the rights of the Indians" and others in the newly conquered Latin American world. 96 And las Casas was a brilliant apostle for religious freedom whose writings influenced key figures on both sides of the Atlantic. 97

The medieval canon law formulations of rights and liberties had parallels in the common law and civil law texts of the Middle Ages. Particularly notable sources of rights were the hundreds of eleventh- to sixteenth-century treaties, concordats, charters, and other constitutional texts that were issued by various religious and secular authorities of the day. These were often detailed - and sometimes very flowery and elegant - statements of the rights and liberties to be enjoyed by defined groups of clergy, nobles, barons, knights, urban councils, citizens, universities, guilds, fraternities, hospitals, orphanages, monasteries, cloisters, and others. These charters were often highly localized instruments, but occasionally they applied to whole territories and nations. A famous example was the Magna Carta (1215), the great charter issued by the English Crown at the insistence of the restive barons of England and drafted under the guidance of Archbishop of Canterbury, Stephen Langton. The Magna Carta guaranteed that "the Church of England shall be free [libera] and shall have all her whole rights [iura] and liberties [libertates] inviolable." It also provided that all "free-men" [liberis hominibus] were to enjoy sundry "liberties" [libertates]. These included sundry rights to property, marriage, and inheritance, to freedom from undue military service, and to freedom to pay one's debts and taxes from the property of one's own choosing. The Magna Carta also set out various rights and powers of towns and of local justices and their tribunals, various rights and prerogatives of the king and of the royal courts, and various criminal procedural rights which, by the fourteenth century, were called the

95 Annabel S. Brett, Liberty, Right, and Nature: Individual Rights in Later Scholastic Thought (Cambridge and New York: Cambridge University Press, 1997); R. W. Davis, ed., The Origins of Modern Freedom in the West (Stanford: Stanford University Press, 1995); Richard Tuck, Natural Rights Theories: Their Origins and Development (Cambridge and New York: Cambridge University Press, 1979); Michel Villey, La formation de la pensée juridique moderne (Paris: Presses Universitaires de France, 1968); id., Le droit et les droits de l'homme (Paris: Presses Universitaires de France, 1983).

96 Francisco de Vitoria, De Indis et de jure belli relectiones, ed. Ernst Nys, trans. John P. Bate, rev. Herbert F. Wright (Washington, DC: Carnegie Institution, 1917).

97 See Bartolomé de las Casas, In Defense of the Indian: The Defense of the Most Reverend Lord, Don Fray Bartolomé de las Casas, of the Order of Preachers, Late Bishop of Chiapa, trans., Stafford Poole, (DeKalb, IL: Northern Illinois University Press, 1992); Lewis Hanke, All Mankind is One: A Study of the Disputation Between Bartolomé de las Casas and Juan Ginés de Sepulveda in 1550 on the Intellectual and Religious Capacity of the American Indians (Dekalb, IL: Northern Illinois University Press, 1974). See David Lantigua, "The Image of God, Christian Rights Talk, and the School of Salamanca," Journal of Law and Religion [cite forthcoming issue] The Max Plank Institute for European Legal History is assembling a comprehensive virtual library of these Salamanca gems.

http://www.rg.mpg.de/research/academy project mainz 
"rights of due process." 98

The Magna Carta and other medieval charters of rights became important prototypes on which later revolutionaries would call to justify their revolts against arbitrary and tyrannical authorities. Among others, early modern Protestant revolutionaries in France, Scotland, the Netherlands, England, and America all reached back to these chartered rights to justify their revolutions against tyrants, and eventually reached beneath these charters to the natural laws and rights and the classical and biblical teachings on which they were founded.99 And the Magna Carta itself provided the foundation for an ever expanding system of rights at Anglo-American common law. By the time William Blackstone sat down to write his famous Commentaries on the Laws of England (1765), he opened his first volume with a lengthy list of public, private, penal, and procedural rights taught variously by the common law, civil law, canon law, Roman law, natural law, and law of nations. 100

Early Modern Protestantism. While "freedom of the church" was the manifesto of the twelfth-century Papal Revolution, "freedom of the Christian" was the manifesto of the sixteenth-century Protestant Reformation. Martin Luther, Thomas Cranmer, Menno Simons, John Calvin, and other leading sixteenth-century reformers all began their Protestant movements with a call for freedom from the medieval Catholic Church freedom of the individual conscience from intrusive canon laws and clerical controls, freedom of political officials from ecclesiastical power and privileges, freedom of the local clergy from central papal rule and oppressive princely controls. "Freedom of the Christian" became the rallying cry of the early Reformation. It drove theologians and jurists, clergy and laity, princes and peasants alike to denounce canon laws and ecclesiastical authorities with unprecedented alacrity, and to urge radical reforms in church, state, and society. The church's canon law books were burned. Church courts were closed. Monastic institutions were confiscated. Endowed benefices were dissolved. Church lands were seized. Clerical privileges were stripped. Mandatory celibacy was suspended. Indulgence trafficking was condemned. Annates to Rome were outlawed. Ties to the pope were severed. Appeals to the papal rota were barred. Each nation, each church, and each Christian was to be free. 101

Left in such raw and radical forms, this early Protestant call for freedom was a recipe for lawlessness and license, as Luther learned the hard way during the Peasants' Revolt of 1525. Luther and other Protestants soon came to realize that structures of law and authority were essential to protecting order and peace, even as guarantees of liberties and rights were essential to preserving the message and momentum of the

98 See John Witte, Jr., "A New Magna Carta for the Early Modern Common Law: An $800^{\text {th }}$ Anniversary Essay," (herein).

99 See John Witte, Jr., The Reformation of Rights: Law, Religion, and Modern Human Rights in Early Modern Calvinism (Cambridge: Cambridge University Press, 2007).

100 William Blackstone, Commentaries on the Laws of England, 4 vols. (Oxford: Oxford University Press, 1765), bk. 1, chap. 1.

101 See Martin Luther, The Freedom of a Christian, in Timothy Lull and William Russell, eds., Martin Luther's Basic Theological Writings, third ed. (Minneapolis, MN: Fortress Press, 2012), 403-427. 
Reformation. The challenge for early Protestants was to strike new balances between authority and liberty, order and rights on the strength of cardinal biblical teachings.

One important Protestant contribution to the Western rights tradition was their effort to define the nature and authority of the family, the church, and the state vis-à-vis each other and their subjects. Most Protestant Reformers regarded these three institutions as fundamental orders of creation, equal before God and each other, and vested with certain natural duties and qualities that the other authorities could not trespass. Defining these institutions, and their respective offices served to check the natural appetite of the paterfamilias, patertheologicus, and paterpoliticus for tyranny and abuse. It also helped to clarify the rights and liberties of those subject to their authority, and to specify the grounds on which they could protest or disobey in the event of chronic abuse or tyranny. 102

A second major contribution was the Protestant Reformers' habit of grounding rights in the duties of the Decalogue and other biblical moral teachings. The First Table of the Decalogue, they argued, prescribes duties of love that each person owes to God - to honor God and God's name, to observe the Sabbath day and to worship, to avoid false gods and false swearing. The Second Table prescribes duties of love that each person owes to neighbors - to honor one's parents and other authorities, not to kill, not to commit adultery, not to steal, not to bear false witness, not to covet. The Reformers cast the person's duties toward God as a set of rights that others could not obstruct the right to religious exercise: the right to honor God and God's name, the right to rest and worship on one's Sabbath, the right to be free from false gods and false oaths. They cast a person's duties towards a neighbor, in turn, as the neighbor's right to have that duty discharged. One person's duties not to kill, commit adultery, steal, or bear false witness thus gives rise to another person's rights to life, property, fidelity, and reputation. 103

Third, the Protestant Reformation permanently broke the unity of Western Christendom, and introduced the foundations for the modern constitutional system of confessional pluralism - at the territorial, national, community, or congregational levels. The Lutheran Reformation territorialized the faith through the principle of cuius regio, eius religio ("whosever region, his religion"), established by the Religious Peace of Augsburg in 1555.104 Under this principle, princes or city councils were authorized to prescribe the appropriate forms of Lutheran or Catholic doctrine, liturgy, and education for their polities. Religious dissenters were granted the right to worship privately in their homes or to emigrate peaceably from the polity. After decades of bitter civil war, the Peace of Westphalia in 1648 extended this right to Reformed Calvinists as well, rendering Germany and beyond a veritable honeycomb of religious pluralism for the

102 John Witte, Jr., Law and Protestantism: The Legal Teachings of the Lutheran Reformation (Cambridge and New York: Cambridge University Press, 2002).

103 Ibid., 121-168; Witte, The Reformation of Rights, 81-142, 209-276.

104 See Sidney Z. Ehler and John B. Morrall, Church and State through the Centuries: A Collection of Historic Documents With Commentaries (Westminster, MD: Newman Press, 1954), 164-173. 
next two centuries. 105

The Anglican Reformation nationalized the faith through the famous Supremacy Acts and Acts of Uniformity passed by the English Parliament between 1534 and 1559.106 Citizens of the Commonwealth of England were required to be communicants of the Church of England, subject to the final ecclesiastical and political authority of the Monarch. The Toleration Act of 1689 extended a modicum of rights to some Protestant dissenters. 107 But it was not until the Catholic and Jewish Emancipation Acts of 1829 and 1833 that the national merger of the Church and Commonwealth of England was finally formally broken, and all non-Anglicans could enjoy the full rights of citizenship.108

The Anabaptist Reformation communalized the faith by introducing what Menno Simons once called the Scheidingsmaurer- "the wall of separation" between the redeemed realm of religion and the fallen realm of the world. Anabaptist religious communities were ascetically withdrawn from the world into small, self-sufficient, intensely democratic communities, governed internally by biblical principles of discipleship, simplicity, charity, and Christian obedience. When such communities grew too large or too divided, they deliberately colonized themselves, eventually spreading the Anabaptist communities from Russia to Ireland to the furthest frontiers of North America. 109

The Calvinist Reformation congregationalized the faith by introducing rule by a democratically-elected consistory of pastors, elders, and deacons. In John Calvin's day, the Geneva consistory was still appointed and held broad personal and subject matter jurisdiction over all members of the city. By the seventeenth century, most Calvinist communities in Europe and North America reduced the consistory to an elected, representative system of government within each church. These consistories featured separation among the offices of preaching, discipline, and charity, and a fluid, dialogical form of religious polity and policing centered on collective worship and the congregational meeting.

Fourth, the Protestant Reformation broke the primacy of corporate Christianity and gave new emphasis to the role of the individual believer in the economy of salvation. The Protestant Reformation did not invent the individual, as too many exuberant commentators still maintain. But sixteenth-century Protestant reformers, more than their Catholic contemporaries, gave new emphasis to the (religious) rights and liberties of individuals at both religious law and civil law.

105 Ibid., 189-192.

106 Carl Stephenson and Frederick B. Markham, Sources of English Constitutional History, rev. ed., (New York: Harper and Row, 1972), 303-321.

107 Ibid., 607-608. See also Joseph Lecler, Toleration and the Reformation, 4 vols., trans. T.L. Westow (New York: Association Press, 1960).

108 In Ehler and Morrall, Church and State through the Centuries, 254-271.

109 Walter Klaassen, ed., Anabaptism in Outline: Selected Primary Sources (Scottdale, PA: Herald Press, 1973); Robert M. Friedmann, The Theology of Anabaptism (Scottdale, PA: Herald Press, 1973). 
Several factors shaped this trend. One central contribution came with the Anabaptist doctrine of adult baptism, which gave new emphasis to a voluntarist understanding of religion, as opposed to conventional notions of a birthright or predestined faith. The adult individual was now called to make a conscientious choice to accept the faith-metaphorically, to scale the wall of separation between the fallen world and the realm of religion and come into the garden of religion which God cultivated. Later Free Church followers converted this cardinal image into a powerful platform of liberty of conscience and free exercise of religion not only for Christians but also eventually for all peaceable religious practitioners.

The Great Awakening (ca. 1720-1780) in America built on this early Anabaptist vision. The various Evangelical denominations and movements that emerged from the Great Awakening emphasized Christian conversion, the necessary spiritual rebirth of each sinful individual. On that basis, they strongly advocated the liberty of conscience of each individual along with the free speech and press rights and duties of the missionary to proselytize, both on the American frontier and abroad. Evangelicals, moreover, had a high view of the Christian Bible as the infallible textbook for human living. On that basis, they celebrated the use of the Bible in chapels, classrooms, prisons, and elsewhere. And Evangelicals emphasized sanctification, the process of each individual becoming holier before God, neighbor, and self. On that basis, they underscored a robust ethic of spiritual and moral progress, education, and improvement of all. These views eventually had a great influence on the formation of constitutional protections of religious liberty in eighteenth- and nineteenth-century America.

Calvinist Reformers set out an ever more expansive theory and law of individual rights. Many early Calvinist leaders were trained in both theology and law, and they talked as freely about subjective rights as lawyers did. Calvin, for example, spoke about the "the common rights of mankind" (iura commune hominum), the "natural rights" (iura naturali) of persons, the "rights of a common nature," (communis naturae iura), or the "the equal rights and liberties" (pari iura et libertates) of all.110 Half a century later, Calvinist jurist Johannes Althusius laid out a comprehensive system of what he called spiritual or religious rights and liberties (iura et libertates religionis); and (2) temporal or civil rights and liberties (iura et libertates civile), drawn variously from the Bible, the Talmud, Roman law, the medieval ius commune, and the Spanish neo-scholastics in Salamanca.111 In 1641, New England jurist and theologian, Nathaniel Ward, drew all these insights together in a 6,200-word Body of Liberties for the new colony of Massachusetts Bay. 112

Early modern Calvinists also grounded these rights in the signature Protestant teaching first made famous by Luther, that every person is both saint and sinner (simul iustus et peccator).113 On the one hand, they argued, a person is created in the image

110 See detailed sources in Witte, The Reformation of Rights, 56-59.

111 Ibid., 169-181.

112 See Witte, "A New Magna Carta for the Early Modern Common Law" (herein).

113 See John Witte, Jr., God's Joust, God's Justice: Law and Religion in Western Tradition (Grand Rapids, Mich. and Cambridge: Wm. B. Eerdmans Publishing Co, 2006), 49-62. 
of God and justified by faith in God. The person is called to a distinct vocation, which stands equal in dignity and sanctity to all others. The person is prophet, priest, and king, and responsible to exhort, minister, and rule in the community. Each person, therefore, stands individually and equally before God. Each person is vested with a natural liberty to live, to believe, and to serve God and neighbor. Each person is entitled to the vernacular Scripture, to education, and to work in a vocation. On the other hand, human beings are sinful and prone to evil and egoism. All persons need the restraint of the law to deter them from evil and to drive them to repentance. All persons need the natural association of others to exhort, minister, and rule them with law and with love. All persons, therefore, are inherently communal creatures, symbiotically bonded with families, churches, and political communities.

These Protestant teachings helped to inspire many of the early modern revolutions fought in the name of human rights and democracy.114 They were the driving ideological forces behind the revolts of the French Huguenots, Dutch Pietists, and Scottish Presbyterians against their monarchical oppressors in the later sixteenth and seventeenth centuries. They were critical weapons in the arsenal of the revolutionaries in England, America, and France. They were important sources of the great age of democratic construction in later eighteenth and nineteenth-century America and Western Europe.115

Enlightenment Reforms. While medieval Catholics grounded rights in natural law and ancient charters, and while early modern Protestants grounded them in biblical texts and theological anthropology, Enlightenment writers in Europe and North America grounded rights in human nature and the social contract. Building in part on the ancient ideas of Cicero, Seneca, and other Stoics of a pre-political state of nature, as well as on Calvinist ideas of covenant community, John Locke, Jean Jacques Rousseau, Thomas Jefferson, and others argued for a new contractarian theory of human rights and political order. Each individual person, they argued, was created equal in virtue and dignity, and vested with inherent and unalienable rights of life, liberty, and property.

Each person was naturally capable of choosing his or her own means and measures of happiness without necessary external references or divine commandments. In their natural state, or in "the state of nature," all persons were free to exercise their natural rights fully. But life in this state of nature was at minimum "inconvenient," as Locke put it - if not "brutish, nasty, and short," as Thomas Hobbes put it. For there was no means to balance and broker disputes between one person's rights against all others, no incentive to invest or create property or conclude contracts when one's title was not sure, no mechanism for dealing with the needs of children, the weak, the disabled, the vulnerable. As a consequence, rational persons chose to move from the state of nature into societies with stable governments. They did so by entering into social contracts and ratifying constitutions to govern their newly created societies. By these instruments, persons agreed to sacrifice or limit some of their natural rights for the sake of creating a measure of social order and peace. They also agreed to delegate their

114 See Harold J. Berman, Law and Revolution II: Faith and Order: The Reconciliation of Law and Religion (Grand Rapids: Wm. B. Eerdmans, 1993), 83-139.

115 John Witte, Jr., Christianity and Democracy in Global Context (Boulder, CO: Westview Press, 1993). 
natural rights of self-rule to elected officials who would represent and exercise executive, legislative, and judicial authority on their behalf. But, at the same time, these social and political contracts enumerated the various "inalienable" rights that all persons were to enjoy without derogation, and the conditions of "due process of law" under which "alienable" rights could be abridged or taken away. And these contracts also stipulated the right of the people to elect and change their representatives in government, and to be tried in all cases by a jury of their peers.

These new Enlightenment views helped shape the American and French constitutions, in particular. The Virginia Declaration of Rights (1776), for example, provided in Article I: "That all men are by nature equally free and independent, and have certain inherent rights, of which, when they enter into a state of society, they cannot, by any compact, deprive or divest their posterity; namely, the enjoyment of life and liberty, with the means of acquiring and possessing property, and pursuing and obtaining happiness and safety." The Declaration went on to specify the rights of the people to vote and to run for office, their "indubitable, unalienable, and indefeasible right to reform, alter or abolish" their government if necessary, various traditional criminal procedural protections, the right to jury trial in civil and criminal cases, freedom of press, and various freedoms of religion. But the Declaration also reflected traditional Christian sentiments in Articles 15 and 16: "[N]o free government, or the blessings of liberty, can be preserved to any people but by a firm adherence to justice, moderation, temperance, frugality, and virtue and by frequent recurrence to fundamental principles." And "it is the mutual duty of all to practice Christian forbearance, love, and charity towards each other."116 In this formulation, subjective rights were qualified and complemented by traditional moral virtues and duties. Even stronger such qualifications stood alongside new Enlightenment views in the 1780 Massachusetts Constitution and in other New England state constitutions. 117

The 1791 Bill of Rights, amended to the 1787 United States Constitution, provided a new set of rights of national citizenship to be enforced by the new federal courts. While the Constitution itself had spoken generically of the "blessings of liberty" and specified a few discrete "privileges and immunities" in Articles I and IV, it was left to the Bill of Rights to enumerate the rights of American citizens. The Bill of Rights guaranteed the freedoms of religion, speech, assembly, and press, the right to bear arms, freedom from forced quartering of soldiers, freedom from illegal searches and seizures, various criminal procedural protections, the right to jury trial in civil cases, the guarantee not to be to be deprived of life, liberty, or property without due process of law, and the right not to have private property taken for public use without just compensation. This original Bill of Rights was later augmented by several other amendments, the most important of which were the right to be free from slavery, the right to equal protection and due process of law, and the right for all adults, male and

116 In Francis N. Thorpe, ed., The Federal and State Constitutions, Colonial Charters, and Other Organic Laws, 7 vols., (Washington, D.C.: Government Printing Office, 1909), 7:3813.

117 See John Witte, Jr., "'A Most Mild and Equitable Establishment of Religion: John Adams and the Massachusetts Experiment," Journal of Church and State, 41 (1999), pp. 213-252. 
female, to vote. 118 The Bill of Rights was defended in its day on a variety of grounds with Enlightenment arguments among the most well-known today. But it is no small commentary for this symposium that, by 1650 , every one of these guarantees in the United States Bill of Rights had already been defined, defended, and died for by Christian writers - Catholics and Protestants on both sides of the Atlantic.

Enlightenment arguments proved more singularly decisive in shaping the French Declaration of the Rights of Man and Citizen (1791). This signature instrument, which revolutionized a good deal of Western Europe, enumerated various "natural, unalienable, and sacred rights," including liberty, property, security, and resistance to oppression, "the freedom to do everything which injures no one else," the right to participate in the foundation and formulation of law, a guarantee that all citizens are equal before the law and equally eligible to all dignities and to all public positions and occupations, according to their abilities. The Declaration also included basic criminal procedural protections, freedom of (religious) opinions, freedoms of speech and press, and rights to property. 119 Both the French and American constitutions and declarations were essential prototypes for a whole raft of constitutional and international documents on rights that were forged in the next two centuries.

\section{The Challenges of Christianity and Human Rights}

The development and refinement of human rights norms in national and international law have made "rights" the dominant mode of political, legal, and moral discourse in the modern West and beyond. Rights protections and violations are increasingly prominent issues in international relations and diplomacy. Most nationstates now have detailed bills or recitations of rights in their constitutions, statutes, and cases. The United Nations and various other groups of nation-states have detailed catalogues of rights set out in treaties, declarations, conventions, and covenants. Many Christian denominations and ecumenical groups, alongside other religious groups, have their own declarations and statements on rights as well and have been instrumental in the development of the major international human rights instruments. 120 Thousands of governmental, intergovernmental, and non-governmental organizations are now dedicated to the defense of rights around the world, including a large number of Christian and other religious lobbying and litigation groups. But, should "rights talk" be such a dominant moral and legal language among Christians today? Do the ideas and institutions underlying today's human rights paradigms adequately express the values and meet the needs - of the modern world and its peoples?

Mapping the Challenges. Several Christian scholars have argued that the

118 U.S. Constitution, preamble; Arts. 1.9, 1.10, IV; Amendments 1-8, 13-15, 19, 24, 26, reprinted with many prototypes and defenses in Philip B. Kurland and Ralph S. Lerner, eds., The Founders' Constitution, 5 vols. (Indianapolis: Liberty Fund, 2000).

119 In Léon Duguit, Les Constitutions et les Principales Lois Politiques de la France Depuis, $4^{\text {th }}$ ed., (Paris: R. Pichon et Durand-Auzias, 1925), 1.

120 See Samuel Moyn, Christian Human Rights (Philadelphia: University of Pennsylvania Press, 2015). 
language of rights, though not entirely foreign to Christianity, is, in its modern forms, inconsistent with Christian faith and practice. In his contribution to this symposium, leading Christian ethicist Stanley Hauerwas argues that rights are conceptually and practically inadequate. 121 Hauerwas acknowledges that "the appeal to rights has been a means to protect those who have no protection in the world in which we find ourselves." He further recognizes that such appeals have "provided for many a moral identity otherwise unavailable." Yet Hauerwas worries that reflexive and repeated "appeals to rights" "threaten to replace first order moral descriptions in a manner that makes us less able to make the moral discriminations that we depend upon to be morally wise." 122 For example, "If you need a theory of rights to know that torture is morally wrong," Hauerwas writes, "then something has clearly gone wrong with your moral sensibilities." 123

Hauerwas seems most troubled by rights that entitle individuals to choose and act in socially unbounded ways. The right and freedom "to do everything which injures no one else," as the French revolutionaries put it in the 1791 Declaration of the Rights of Man and Citizen, is at once too abstract and too diffuse to sustain the requisite moral commitments and judgments implicit in the recognition that all persons share a common humanity. "No real society can exist when its citizens' only way of relating is in terms of noninterference" with one another. ${ }^{124}$ Quoting Simone Weil, he adds:

the right to choose divorced from the rules that make life together possible can result in the loss of the enjoyment liberty should provide. That loss means people "must either seek refuge in irresponsibility, puerility, and indifference-a refuge where the most they can find is boredom-or feel themselves weighted down by the responsibility at all times for fear of causing harm to others." 125

Hauerwas only hints here at the rich eschatological vision of Christian community and moral virtue that he has developed in several other writings. Here, he simply notes that rights have a contingent and milquetoast character when placed alongside the stronger moral norms and narratives that are at the heart of Christian teachings. Rights, he says, may aptly describe a vendor's legal capacity to sell goods, or a bank's ability to make a loan. But much more is needed to convey the gravity of the wrongs of, say, child prostitution, rape, or murder, or the seriousness of the commands to love God, neighbor, and self. Rights claims inevitably reflect a tone of envy, of grasping, of selfpromotion. They thus have only a "mediocre character," reflecting a "vocabulary of middle values" that are simply too weak to account for gross injustices or the serious commands of faith, hope and love. Concepts like "truth, beauty, justice, and

121 See esp. Hauerwas, The Hauerwas Reader, chaps. 4, 6, 7, 8, 9, 11, 12, 16, 21, 22, 26, 28, 31. 122 See Hauerwas, "How to Think Theologically About Rights" (herein, esp. at pp. 1, 14 of transcript.) $123 \mathrm{lbid}$., 4. (page num. refers to draft/transcript)

124 Ibid., 3 and Stanley Hauerwas, Suffering Presence: Theological Reflections on Medicine, the Mentally Handicapped, and the Church. (Notre Dame: University of Notre Dame Press, 1986), 130. 125 Hauerwas, "How to Think Theologically About Rights," at 14. (page num. refers to draft/transcript) 
compassion" are the stronger and sterner concepts we need for the serious moral and social issues that any community regularly faces.126 While rights may depend on or refer to deeper moral values and relationships, reflexive appeals to rights are more likely to eclipse engagement with the moral dimensions of social life and replace them with a "shrill nagging of claims and counter-claims, which is both impure and unpractical." 127 Thus, even if rights can play a legitimate role in legal spheres, rights are not morally basic or absolute, and distract us from morality. Rights might be "reminder claims to help us remember the thick moral relationships" that become the Christian life.128 But Christians would do well to jettison rights from their moral vocabularies per se for fear of cheapening their moral discourse, or thinning their moral character. ${ }^{129}$

Distinguished Christian jurist, Patrick Parkinson cautions against human rights not because they are morally thin, but because they are morally thick. In his native Australia, Parkinson argues, human rights norms come laden with thick liberal values that too often conflict with the religious and moral teachings of Christian churches and other religious institutions. To accept a human rights regime is to risk capitulation to these liberal values, he argues. Several Christian leaders in Australia have thus spoken out against adding a bill of rights to the Australian constitution, which is the only Western constitution without a bill of rights. Australian Christians worry that evolving cultural norms, together with untested provisions about gender and same-sex discrimination, will jeopardize churches in their ability to select their own clergy and teachers, or to enforce traditional moral and religious norms among their memberships. They worry further that those advocating human rights in Australia "do not take freedom of religion and conscience nearly seriously enough."130 Other common law lands, Parkinson and others point out, are now facing a sustained argument that religion has no special claim to human rights, and that religious freedom, if protected at all, must take second place to other fundamental human rights claims in the event of conflict.131

This subordination of religious freedom to other fundamental rights claims is what concerns leading Catholic legal scholar Helen Alvare in her contribution to this symposium. Alvare is particularly concerned that norms of sexual liberty, privacy, and autonomy are threatening to eclipse religious liberty in the United States. Already in the ur case of Griswold v. Connecticut (1965), 132 she argues, the United States Supreme Court affirmed the right of married heterosexual couples to have access to contraceptives owing, in part, to the deeply "private" nature of marital relationships and the decision of married couples to procreate. In subsequent cases, the Court expanded these privacy rights to unmarried individuals, entitling them to make private decisions

126 Ibid. 10-11. (page num. refers to draft/transcript)

127 Ibid., 10.

128 Ibid., 18.

129 Ibid.

130 Patrick Parkinson, "Christian Concerns About an Australian Charter of Rights," in Paul Babie and Neville Rochow, eds., Freedom of Religion under Bills of Rights (Adelaide: University of Adelaide Press, 2012), 150.

131 Ibid.,137-139.

132 Griswold v. Connecticut, 381 U.S. 479 (1965). 
about their own sexual relationships, including the gender of their sexual partner(s), and the use of birth control and abortion as contraceptive methods. This resulting sphere of constitutionally-protected privacy, Alvare argues, has gradually come into conflict with First Amendment's religious liberty norms. When the law mandates pharmacists or employers to participate in the delivery of contraceptives, or prohibits religious employers from regulating the sexual morality of their employees, or insists that photographers or bakers service the weddings of same-sex couples - this has a direct and dramatic impact on Roman Catholic institutions and individuals who adhere to the Church's official teachings about contraception, abortion, marriage, and sexual expression. These teachings are so deeply bound to Catholic cosmology, Alvare argues, that "coercing Catholics to facilitate opposing practices is tantamount to coercing them to abandon their own religion and to practice another."133

Leading Black Church and African-American studies expert Robert Franklin warns in his contribution to this symposium that the American human rights movement is increasingly passing by the very African-American communities that were so vital in building the case for the Civil Rights Act of 1964 and the Voting Rights Act of 1965.134 These two acts ostensibly put an end to the "separate but equal" legal status of racial minorities in the United States, he argues. But, despite the formal equality mandated by these acts, recent studies show startling disparities in America's criminal justice system. African-American men make up a disproportionate share of the total prison population in the United States, which ballooned from fewer than 350,000 in 1972 to more than 2.2 million today. African Americans make up only 12 percent of the overall population, but constitute 37 percent of all inmates. 135 Roughly one-third of all African American men are currently under the control of state or federal prison systems - either in prison or jail, on probation, or on parole. 136

Researchers debate the underlying causes of criminal behavior, and the political motivations behind American law enforcement policies such as the "war on drugs," which has led to increased rates of arrest and incarceration. ${ }^{137}$ A growing number of scholars, however, see troubling similarities between the modern criminal justice system and the "Jim Crow" laws in place prior to the civil rights era. These scholars point out apparent racial biases and dubious practices affecting the enforcement and adjudication of drug-related and other criminal laws. 138 They also point out the increasing scope of "collateral consequences" that are often attached to criminal convictions, including "disenfranchisement, loss of professional licenses, and deportation in the case of aliens,

\footnotetext{
133 Alvare, "Religious Freedom v. Sexual Expression: A Guide," at p. 3 in transcript.

134 Franklin, "Rehabilitating Democracy: Restoring Civil Rights and Leading the Next Human Rights Revolution."

135 E. Ann Carson, "Prisoners in 2013," (Washington, DC: U.S. Dept. of Justice, Office of Justice Programs, Sept. 30, 2014), 16.

136 Michelle Alexander, The New Jim Crow: Mass Incarceration in the Age of Colorblindness (New York: New Press, 2010), 9.

137 See, e.g., James Forman, Jr., "Racial Critiques of Mass Incarceration: Beyond the New Jim Crow," New York University Law Review 87 (2012): 21-69.

138 Marc Mauer, Race to Incarcerate, rev. ed. (New York: New Press, 2006).
} 
as well as newer penalties such as felon registration and ineligibility for certain public welfare benefits."139 The disproportionate incarceration and disenfranchisement of racial minorities, and the substantial barriers imposed by the criminal justice system to their rehabilitation and re-entry into their communities have dire implications for racial equality and for the long-term wellbeing of the nation as a whole. There are serious rights claims at stake when criminal penalties contribute to, rather than mitigate, the breakdown of families and other community structures. These issues deserve the sustained attention of, among others, Christian scholars who are interested in fostering a just legal and social order.

Not only racial minorities in the United States, but also religious minorities around the world are facing increasing oppression and persecution, even as human rights instruments in favor of their protection have become increasingly detailed and more prominent in international diplomacy and news coverage. A 2009 comprehensive study documents that more than a third of the 198 countries and self-administering territories in the world today have "high" or "very high" levels of religious oppression, sometimes exacerbated by civil war, natural disasters, and foreign invasion that have caused massive humanitarian crises. The countries on this dishonor roll include Iran, Iraq, India, Pakistan, Bangladesh, Sri Lanka, Indonesia, Saudi Arabia, Somalia, Yemen, Sudan, Egypt, Israel, Burma, Rwanda, Burundi, the Congo, Chechnya, Uzbekistan, among others. 140 The most recent annual report of the U.S. Commission on International Religious Freedom confirms the precarious status of religious minorities in many parts of the world, now exacerbated by the rise of ISIS in the Middle East and the escalating oppression of Muslim and Christian minorities in various parts of the world, including Western lands. 141 Western readers may be surprised to learn that Christians are among the most persecuted religious groups around the world today. A 2014 study found that Christians were more widely harassed than the members of any other religious tradition, experiencing social and political hostility in at least 110 countries. ${ }^{142}$ These hostilities were carried out by a variety of private groups and governmental entities, and included arrests and detentions, desecration of holy sites, denial of visas, corporate charters, and entity status, and discrimination in employment, education and housing, closures of worship centers, schools, charities, cemeteries, and religious services - let alone outright rape, torture, kidnapping, and slaughter of religious

\footnotetext{
139 American Bar Association, "ABA Standards for Criminal Justice, $3^{\text {rd }}$ Edition: Collateral Sanctions and Discretionary Disqualifications of Convicted Persons," (2004), p. 7-8

140 The Pew Forum on Religion and Public Life, Global Restrictions on Religion," (December, 2009) (www.pewforum.org); Allen D. Hertzke, ed., The Future of Religious Freedom: Global Challenges (Oxford: Oxford University Press, 2013); Timothy Shah and Allen D. Hertze, eds., Christianity and Freedom: Historical and Contemporary Perspectives, 2 vols. (Cambridge: Cambridge University Press, 2015). 141 Annual Report 2014: $15^{\text {th }}$ Anniversary Retrospective: Renewing the Commitment (Washington, DC: U.S. Commission on International Religious Freedom, 2014).

142 See Pew Research Center, January 2014, "Religious Hostilities Reach Six-Year High," at 21. By comparison, Muslims were harassed in 109 countries; Jews in 71; "others" (e.g. Sikhs, Zoroastrians, Baha'i, etc.) in 40 countries; "folk religionists" in 26 countries; Hindus in 16 countries; Buddhists in 13 countries.
} 
believers in alarming numbers of war-torn areas of the Middle East and Africa. ${ }^{143}$ Even while some Western Christians rest comfortably on their tenured rights and liberties and now question the theological validity, moral value, or even social utility of rights, many Christians and other religious believers have become increasingly desperate to secure the most basic of human rights protections.

Facing the Challenges. We submit that rights should remain part of Christian moral, legal, and political discourse, and that Christians should remain part of broader public debates about human rights and public advocacy for their more expansive protection and implementation. We agree with those Christian skeptics today who criticize the utopian idealism of some modern rights advocates, the reduction of rights claims to groundless and self-interested wish lists, the monopoly of rights language in public debates about morality and law, and the dominant liberalism of much contemporary rights talk. We also recognize that Christian believers and churches will inevitably vary in their approaches to human rights - from active involvement in litigation, lobbying, and legislation to quiet provision for the poor, needy, and strangers in their midst. In the church, the Bible reminds us, "[t]here are varieties of gifts, but the same Spirit; and there are varieties of service, but the same Lord."144

We further acknowledge that some rights recognized today are more congenial to Scripture, tradition, and Christian experience than others. In the introduction to this Article we highlighted nine common classes of rights - subjective and objective rights; natural and positive rights; public and private rights; individual and group rights; substantive and procedural rights; human and civil rights; unalienable and alienable rights; will theory and interest-based rights; first generation civil and political rights, second generation social, cultural, and economic rights, third generation rights to peace, order, and environmental protection. We also drew out four jural relationships that cut across these types of rights - rights and privileges, active and passive rights, privileges and immunities, positive and negative rights and liberties. Most of these rights classifications, and others, we have shown in our historical overview, were drawn by Christian jurists, moralists, and philosophers from the fourth to the eighteenth centuries. And these rights were - and still are - applied to different areas of law and life. Family laws, for example, protect the reciprocal rights and duties of spouses, parents, and children at different stages of the life cycle. Social welfare rights speak to the basic human need for food, shelter, health care, and education - especially for vulnerable populations. Free speech and free press laws protect the rights of persons to speak, preach, and publish. Private and public laws protect the person's rights to contractual performance, to property and inheritance, to the safety and integrity of their bodies, relationships, and reputations, along with the procedural means to vindicate these rights when they are threatened or breached by another. Criminal procedural rights are designed to ensure an individual of proper forms of arrest and detention, fair hearings

143 Pew Research Center, January 2014, "Religious Hostilities Reach Six-Year High," at 21. See further W. Cole Durham, Jr. Matthew K. Richards, and Donlu D. Thayer, "The Status of and Threats to International Law on Freedom of Religion and Belief," in Hertzke, ed., The Future of Religious Freedom, 31-66.

1441 Cor. 12:4-5 (RSV) 
and trails, and of just punishments that are proportionate to specific crimes. Freedom of conscience and the free exercise of religion protect the essential right (and duty) of Christians to love God, neighbor, and self.

When Christians affirm such rights - in defense of themselves or others - they need not abandon their religious and moral traditions, much less defy their duty to love God "with all your heart, and with all your soul, and with all your strength, and with all your mind; and your neighbor as yourself." 145 Stanley Hauerwas is right to warn that rights can become a grammar of greed and grasping, of self-promotion and selfaggrandizement at the cost of one's neighbor and one's relationship to God. But Christians from the start have claimed their rights and freedoms first and foremost in order to discharge the moral duties of the faith. Claiming your right to worship God, to avoid false gods, to observe the Sabbath Day, and to use God's name properly enables you to discharge the duties of love owed to God under the First Table of the Decalogue. Claiming your rights to life, property, and reputation, or to the integrity of your marriage, family, and household gives your neighbor the chance to honor the duties of love in the Second Table of the Decalogue - to not murder, steal, or bear false witness; to not dishonor parents or breach marital vows; to not covet, threaten, or violate "anything that is your neighbor's." 146 To insist on these Second Table rights can also be an act of love towards your neighbors, giving them the opportunity and accountability necessary to learn and discharge their moral duties.

Once viewed this way, many rights claims are not selfish grasping at all - even if they happen to serve one's own interests. Rights claims can reflect and embody love of God and neighbor. The rights claims of the poor and needy, the widow and the orphan, the child and the stranger, and the "least" of society are, in part, invitations for others to serve God and neighbor: "As you did it to one of the least of these...you did it to me," Jesus said. 147 To insist on the rights of self-defense and the protection and integrity of your body or that of your loved ones, or to bring private claims and support public prosecution of those who rape, batter, starve, abuse, torture, or kidnap you or your loved ones is, in part, an invitation for others to respect the divine image and "temple of the Lord" that each person embodies.148 To insist on the right to education and training, and the right to work and earn a fair wage is, in part, an invitation for others to respect God's call to each of us to prepare for and pursue our distinctive vocation.149 To sue for contractual performance, to claim a rightful inheritance, to collect on a debt or insurance claim, to bring an action for discrimination or wrongful discharge from a job serves, in part, to help others to live out the Golden Rule - to do unto others as you would have them do unto you.150 To petition the government for your due process and equal protection rights; to seek compensation for unjust taxes or unlawful takings or searches of your property; to protest governmental abuse, deprivation, persecution, or violence --

\footnotetext{
145 Luke 10:27 (RSV)

146 Exodus 20:17 (RSV).

147 Matt. 25:40 (RSV).

1481 Cor. 3:16.

149 Eph. 4:1.

150 Matt. 7:12.
} 
all these are, in part, calls for political officers to live up to the lofty ideals that the Bible ascribes to the political office. To sue for protection of your freedoms of speech and press or your rights to vote are, in part, a call for others to respect God's generous calling for each of us to serve as a prophet, priest, and king on this earth. 151 And to insist on your freedom of conscience and free exercise of religion is to force others to respect the prerogatives of God, whose loving relationship with his children cannot be trespassed by any person or institution.

These examples, and many others, demonstrate that human rights are not inherently antithetical to Christianity. They are part of the daily currency of life, law, and love in this earthly realm, damaged and distorted as it inevitably is. Rights and their vindication help the law achieve its basic "uses" in this life - the "civil use" of keeping peace, order, and constraint among its citizens even if by force; the "theological use" of driving a person to reflect on their failings and turn to better ways of living in community; and the "educational use" of teaching everyone the good works of morality and love that please God, however imperfect and transient that achievement will inevitably be in the present age. 152

To have and use rights in a fallen world does not mean that Christians must always pursue those rights to their furthest reaches. Just as judges must apply the law equitably, so Christians (and others) must pursue lawful rights claims equitably. Christians are often called to turn the other cheek,153 to forgive debtors, 154 to love enemies, 155 and to settle disputes privately. 156 Such acts of faith can serve important theological and educational "uses" of their own, even without directly engaging the civil law. To love a debtor, defendant, or adversary in such ways is, in part, to "heap burning coals upon his head," 157 to induce him to respect his neighbor's person and property, and to urge him to reform his actions. To forgive an egregious felon - as Pope John Paul II forgave his would-be assassin, 158 or as the Amish forgave those who murdered their school children 159 - is to echo and embody a form of self-sacrifice at the heart of Christian faith. 160 But such acts of faith are atypical precisely because they are exceptions to the usual rules of an earthly order in which laws must be enforced if they are to be effective, and in which rights must be vindicated for the law to fulfill its appropriate civil uses and maintain a basic level of peace and order.

151 See Ps. 82:6, and John Calvin's commentary in Institutes (1536), I.33; 6.48-9; Institutes (1559), 4.20.

152 See Witte, God's Joust, God's Justice, 263-294.

153 Luke 6:29.

154 Matt. 6:12.

155 Matt. 5:44.

1561 Cor. 6.

157 Rom. 12:20-21.

158 Pope John Paul II publicly forgave and requested that Mehmet Ali Ağca be pardoned for an assassination attempt on May 13, 1981.

159 Members of the Old Order Amish Community in Barth Township, Pennsylvania publicly forgave the perpetrator of a mass shooting at the West Nickel Mines School after he murdered five young girls, and wounded five more before committing suicide on October 2, 2006.

160 Luke 23:34. 
To say that rights are useful within the state and civil society is not necessarily to recommend the same set or reach of rights within the church. The state is a universal sovereign; the church is more limited in its membership and reach. The state has ultimate coercive power over life and limb; the church has only spiritual power over its members. The state's authority is inescapable for those who live within its borders; the church's authority rests on voluntary membership. Against the state, rights and liberties have emerged as powerful ways to protect the dignity of individuals, and the integrity of social institutions, from the totalitarian tendencies of those who command political authority. Within the state, rights and liberties have also emerged as an expedient means for citizens and institutions to establish boundaries and bonds with their neighbors, to protect and preserve their property and promises, to negotiate and peaceably litigate their differences, and more. Here, rights are common and useful instruments for social order, peace, and predictability. By contrast, churches operate by different means and measures of fellowship, different norms of keeping order and peace, and different models of authority and submission, love and sacrifice, caring and sharing. Canon law and ecclesiastical structures have some basic rules and rights that are comparable to those of the state. After all, churches are legal entities that deal, in part, in contracts and property, labor and employment, incorporation and procedures for their leadership and members. But rights are a less central means by which believers typically relate to one another in spiritual fellowship.

Finally, to say that human rights are useful and important is not to say that rights constitute a freestanding system of morality, or render Christian moral and religious teachings superfluous. Some contemporary scholars describe human rights as the new religion and catechism of modern liberalism, invented in the Enlightenment to replace tried and tired Christian establishments. Indeed, core human rights can take on nearsacred qualities in modern societies. Moreover, ideals like "liberty, equality, and fraternity," or "life, liberty, and property," or "due process and equal protection of the law" often function as powerful normative totems. Yet modern human rights norms are better understood as the ius gentium of our times - the common law of nations - which a variety of Jewish, Greek, Roman, Patristic, Catholic, Protestant, and Enlightenment movements have historically nurtured in the West, and which today still needs the constant nurture of multiple communities, in the West and beyond. Many formulations of human rights are suffused with the fundamental beliefs and values of modern liberalism, some of which run counter to the cardinal beliefs of various religious traditions, including Christianity. But secular political philosophy does not and should not have a monopoly on the nurture of human rights; indeed, a human rights regime cannot long survive under its exclusive patronage. For human rights are "middle axioms" of political discourse.161 They are a means to the ends of justice and the

\footnotetext{
161 Abdullahi Ahmed An-Na'im, "Towards an Islamic Hermeneutics for Human Rights," in Human Rights and Religious Values: An Uneasy Relationship? ed. Abdullahi Ahmed An-Na'im, et al. (Grand Rapids: Wm. B. Eerdmans, 1995), 229-242; Robert P. George, "Response," in A Preserving Grace: Protestants, Catholics, and Natural Law, ed. Michael Cromartie (Grand Rapids: Wm. B. Eerdmans, 1997), 157-161. Also see Michael J. Perry, Toward a Theory of Human Rights: Religion, Law, Courts (Cambridge: Cambridge University Press, 2008).
} 
common good. But, the norms that rights instantiate depend upon the visions and values of human communities for their content and coherence - or, what the Catholic philosopher Jacques Maritain described as "the scale of values governing [their] exercise and concrete manifestation."162

It is here that Christianity and other religious communities play a vital role - even in modern liberal societies. Religion is a dynamic and diverse, but ultimately ineradicable, condition and form of human community. Religions invariably provide some of the sources and "scales of values" by which many persons and communities govern themselves. Religions help to define the meanings and measures of shame and regret, restraint and respect, responsibility and restitution that a human rights regime presupposes. They help to lay out the fundamentals of human dignity and human community, and the essentials of human nature and human needs upon which rights are built. Moreover, Christianity and other religions stand alongside the state and other institutions in helping to implement and protect the rights of a community - especially in transitional societies, or at times when a once-stable state becomes weak, distracted, divided, or cash-strapped. Churches and other religious communities can create the conditions (sometimes the prototypes) for the realization of first generation civil and political rights of speech, press, assembly, and more. They can provide a critical (sometimes the principal) means to meet second generation rights of education, health care, child care, labor organizations, employment, artistic opportunities, among others. And they can offer some of the deepest insights into norms of creation, stewardship, and servanthood that lie at the heart of third generation rights.

Because of the vital role of religion in the cultivation and implementation of human rights, many social scientists and human rights scholars have come to see that providing strong protections for religious individuals and religious institutions enhances, rather than diminishes, human rights for all. Already a century ago, German jurist Georg Jellinek wrote that religious freedom is "the mother of many other rights." 163 Many other scholars now repeat the American founders' declaration that religious freedom is "the first freedom" from which other rights and freedoms evolve. For the religious individual, the right to believe leads ineluctably to the rights to assemble, speak, worship, evangelize, educate, parent, travel, or to abstain from the same on the basis of one's beliefs. For the religious association, the right to exist implies the rights to corporate property, collective worship, organized charity, parochial education, freedom of press, and autonomy of governance. Several comprehensive studies of the state of religious freedom in the world today have shown that proper protection of "religious freedom in a country is strongly associated with other freedoms, including civil and political liberty, press freedom, and economic freedom, as well as with multiple measures of well-being.... [W]herever religious freedom is high, there tend to be fewer incidents of armed conflict, better health outcomes, higher levels of earned income,

162 Jacques Maritain, "Introduction," in UNESCO, Human Rights: Comments and Interpretations (New York: Columbia University Press, 1949).

163 Georg Jellinek, Die Erklärung der Menschen- und Bürgerrechte: ein Beitrag zur modernen Verfassungsgeschichte (Liepzig: Duncker and Humblot, 1895), 42. 
prolonged democracy and better educational opportunities for women."164

Liberal philosophers, in turn, have come to realize that religion often plays a key role in public life and political deliberation. A generation ago, secularization, privatization, and disestablishment theorists commonly insisted that religion had no serious place in public life, and that political deliberation required secular or utilitarian rationality to be valid. Many asserted that religion could be consigned to the private sphere where it would slowly but inevitably die out, having outlived its utility. Some scholars have maintained these positions. The subsequent growth and transformations of religions around the world, however, have led many others to question the central hypotheses of secularization theory, to reimagine the place of religion in political processes, and to invite people of faith back to the table of public deliberation. Pluralism now outshines strict secularism as a discursive ideal for modern democracies.

Even some of the most influential proponents of religious privatization have accordingly retracted their previous calls to exclude religious norms and idioms from legislative and political discourse. Jürgen Habermas, Richard Rorty, and John Rawls, for example, have all affirmed in their later writings that religion can play valuable and legitimate roles in the lawmaking processes of liberal democracies. 165 They acknowledge that deeply held beliefs are not easily bracketed; that efforts to exclude an entire class of moral and metaphysical knowledge is more likely to yield mutual distrust and hostility than social accord; that free speech norms prohibit banning or discriminating against religion in the public square; and that avowedly secular values are not inherently more objective, in an epistemological sense, than their religious counterparts. Secular norms and idioms can serve as useful discursive resources in religiously pluralistic societies. But purging religion altogether from public life is impractical, short-sighted, and often unjust.

Leading Jewish philosopher, Lenn E. Goodman, offers a viable alternative to the "naked public square" arguments of a generation or two ago.166 Goodman argues that social and communal bonds are forged through authentic encounters with the genuine other. Moral truth and political justice are best approximated when persons bring their best arguments, their deepest convictions, and a sense of mutual respect for one another to the conversation table. He offers "a simple thesis: that we humans, with all

164 Brian J. Grim, "Restrictions on Religion in the World: Measures and Implications," in Hertzke ed., The Future of Religious Freedom, 86-104, at 101. See more fully on the social, political, and economic consequences of religious freedom restrictions in Brian J. Grim and Roger Finke, The Price of Religious Freedom Denied: Religious Persecution and Conflict in the Twenty-First Century (Cambridge: Cambridge University Press, 2011)

165 See, e.g., John Rawls, "The Idea of Public Reason Revisited," University of Chicago Law Review 64 (1997), 765; Jürgen Habermas, et al, An Awareness of What is Missing: Faith and Reason in a Postsecular Age, Ciaran Cronin, trans. (Cambridge, UK and Malden, Mass.: Polity Press, 2010); Richard Rorty, "Religion in the Public Square: A Reconsideration," Journal of Religious Ethics, Vol. 31, Iss. 1, (2003): 141-149.

166 The following paragraphs are adapted from, Justin J. Latterell and John Witte, Jr., "Law, Religion, and Reason in a Constitutional Democracy: Goodman v. Rawls," Journal of Political Theology, (forthcoming). 
our differences in outlook and tradition, can respect one another and learn from one another's ways, without sharing them or relinquishing the commitments we make our own."167 With this in mind, Goodman urges that members of pluralistic societies should not censor themselves, privatize or gloss over their differences, or naively romanticize the exotic other while showing contempt for the more-familiar domestic other. Nor should persons or groups foist sectarian parochialisms on their unreceptive neighbors. Instead, members of pluralistic societies ought to mine their respective moral traditions - including religious and secular moral traditions - for wisdom and insights about how to live together with integrity. "The profit of pluralism," Goodman contends, "is the space it allows for individuals and groups to retain their identity and commitments, not blurring the differences that make all the difference or blunting the seriousness that distinguishes high seriousness from mere entertainment.... [F]ruitful dialogue demands our knowing something about who we are ourselves, what we believe and care about, and how what is other actually is other." 168

Thus, for Goodman, discerning the proper scope and substance of moral and legal norms is anything but an abstract thought experiment conducted behind a hypothetical "veil of ignorance." Rather, it is a real, historical process - an actual debate among actual people who have actual lives and actual beliefs, hopes, fears, plans and needs. "[T]he kind of pluralism I advocate finds its ideal in an ongoing conversation among cultures in all their richness and among individuals in all their uniqueness." When it's done right, such pluralism sharpens a society's values like a whetstone sharpens a blade. "[l]t is in our big ideas," Goodman explains, "that we humans find ways of integrating thoughts with acts and find structural affinities that may help us link our local truths to one another. The logic of our commitments stands in relief as the family resemblances in our diverse ways of thought and action come into focus."169 Such discourse ideally allows religiously diverse persons and groups to learn and evaluate the contours - and limits - of their own moral teachings. Different communities discover which values they hold in common, and which they do not, by exhibiting to one another what they actually believe - not by imagining which values they might hold if they didn't know who they were. In short, the pursuit of justice, both as a concept and as an institutional reality, requires candid and thoroughgoing debates within and between moral communities. "A good government will foster religious thought and expression and promote metaphysical conversation and inquiry, not hide behind a factitious or fictitious scrim of value neutrality."170 Following Goodman, an appropriate posture for Christian scholars working in pluralistic contexts is one of integrity and

167 Lenn E. Goodman, Religious Pluralism and Values in the Public Sphere (New York, NY: Cambridge University Press, 2014), 1. Also see ibid., 86-87: "But religious voices may see harms that contractual models of human relations fail to register...The humanism that invigorates many a religious tradition is protective of human bodies and spirits. It vigorously contests the notion that we human beings are social isolates with no obligations to self or other beyond what we contractually assume.... Religion, at its fairest reach, welcomes daylight unafraid of fair debate, even thoughtful probing of its deepest mysteries. But the public has little to fear in religious thoughts and proposals. What is strictly parochial will not win much purchase in an open society."

168 Goodman, Religious Pluralism, 2-3.

169 Ibid., 107, 79.

170 lbid., 101. 
reciprocity, boldness and humility. In the spirit of Saint Francis of Assisi, Christian scholars should seek not only to be understood by their non-Christian counterparts, but also to understand and empathize with them.

In order to assume their proper place in public deliberation, political law-making, and human rights cultivation, however, Christian believers and churches must embody and exemplify the rights and duties they extol and advocate. Like other institutions, Christian churches are not immune to the vices of their members and leaders. Yet the gross injustices, negligence, and abuses that infect too many Christian institutions today are inexcusable in light of the divine truths and moral ideals they confess. Think of the clerical abuse of minors. The embezzlement of tithes and gifts. The degradation and mistreatment of women. Indifference to the poor and needy. A lack of compassion in matters of sexual orientation. Racially and economically segregated congregations. Inhospitality toward immigrants and foreigners. Wrath. Greed. Sloth. Pride. Lust. Envy. Gluttony. "Therefore you have no excuse... whoever you are, when you judge others," the Bible tells us; "for in passing judgment on [another] you condemn yourself, because you, the judge, are doing the very same things." 171 Our failure as Christians to live up to our own truths and values rightly undercuts our moral authority in the eyes of others. Only by embracing and embodying the truths and values we profess can Christians retain the ability to call out injustices in other social spheres and institutions. Christian communities simply must do more to habitualize, institutionalize, and exemplify respect for basic human rights, especially the rights of vulnerable populations within their midst.

Martin Luther King, Jr. once said that the church "is not the master or the servant of the state, but rather the conscience of the state."172 When their own houses are in good order, churches are well situated to play this important prophetic role. Wellordered churches, in this sense, make for effective thorns in the sides of complacent societies and states. Healthy and vibrant churches are well situated to serve a number of other important functions within society, too. Christian communities that more fully embody the rights and duties they profess can act as a sort of ballast in otherwise turbulent contexts. Like other religious organizations, they can catalyze social, intellectual, and material exchange among citizens; trigger economic, charitable, and educational impulses; provide healthy checks and counterpoints to social and individual excess; build relationships across racial and ethnic boundaries; diffuse social and political crises and absolutisms by relativizing everyday life and its institutions; transmit cultural traditions, wisdom, and memories; provide leadership and aid amidst social crises and natural disasters; form persons in the virtues and skills of civic engagement and shared decision-making processes; provide material aid to the underprivileged and downtrodden members of society; enrich and structure family life and other important relationships; and more. 173 Taken together, these tasks represent a tall order for a

171 Rom. 2:1

172 Martin Luther King, Jr., "A Knock at Midnight," in A Testament of Hope: The Essential Writings of Martin Luther King, Jr., James M. Washington, ed., (San Francisco: Harper and Row, 1986), at 501.

173 For more on the constructive roles of religion in public life, see: Martin E. Marty, Politics, Religion, and the Common Good: Advancing a Distinctly American Conversation about Religion's Role in Our Shared Life (San Francisco, CA: Jossey-Bass, Inc, 2000), esp. Ch. 2; A. James Reichley, Religion in 
community of fallible humans. Yet, as Dr. King reminded his listeners, "if the church will free itself from the shackles of a deadening status quo, and, recovering its great historic mission, will speak and act fearlessly and insistently in terms of justice and peace, it will enkindle the imagination of mankind and fire the souls of men, imbuing them with a glowing and ardent love for truth, justice, and peace. Men far and near will know the church as a great fellowship of love that provides light and bread for lonely travellers at midnight."174

American Public Life (Washington, DC: Brookings Institution Press, 1985); Steven M. Tipton, Public Pulpits: Methodists and Mainline Churches in the Moral Argument of Public Life (Chicago and London: The University of Chicago Press, 2007).

174 King, "A Knock at Midnight," supra. 